\title{
Gemstones of eastern Kazakhstan
}

\author{
Jiri Chlachula \\ Institute of Geoecology and Geoinformation, Adam Mickiewicz University, Krygowskiego 10, 61-680 Poznań, Poland; \\ e-mail: paleo@amu.edu.pl
}

\begin{abstract}
An overview is presented of gemstones from eastern Kazakhstan in terms of their geographical distribution, geological provenance and genesis, gemmological characteristics, historical use and current applications. Locally occurring precious, semi-precious and decorative stones were extracted and traded along the northern part of the Silk Road that traversed the area in earlier historical times. Currently, non-metallic minerals, which largely originate from mafic igneous and metamorphic bodies of the Altay and Kalba Mountains of Kazakhstan, still are insufficiently known and exploited industrially only marginally. For the present study, selected depositories of coloured stones at the Mineralogy Museum of the East Kazakhstan State Technical University were used, supplemented by the newly collected material during personal fieldwork in the southern Altay between 2005 and 2015. Standard documentation of the gemstones selected is provided, alongside with their known occurrence sites and an evaluation of the perspective gemstone-bearing deposits with respect to regional morphostructural bedrock characteristics. The most precious gemstones include topaz, corundum (sapphire and ruby), beryl (emerald and aquamarine), coloured tourmalines, agates as well as diamonds. Despite the great variety, the majority of these traditionally most valued stones are currently commercially not viable, unlike high-quality decorative stones.
\end{abstract}

Key words: Altay, non-metallic mineral deposits, gemstones, decorative stones, prehistory, field exploration, jewellery

\section{Introduction: cultural-historical context of gemstones in eastern Kazakhstan}

Gemstones have always inspired people on account of their aesthetic nature and of being a symbol of lasting value and social superiority (Schumann, 2006; Klein \& Dutrow, 2007; Żaba, 2010; Heflik \& Natkaniec-Nowak, 2011; Polk, 2012; Weinstein, 2013). Jewels, along with gold and silver, have been bound with humanity since ancient times (Smith, 1980). In central Asia, over thousands of years, local gems were seen as attributes of richness and influence and represented the personal status of their bearers in the hierarchy of prehistoric civilisations, early historical (Mongol and Tatar) feudal states and Muslim khaganates (Khazanov, 1984; Barfield, 1989; Baumer, 2016a-c).
The gemstones from eastern Kazakhstan were traded widely, either in rough form or as cut and (semi-) processed gems. Their natural provenance areas are located close to or directly on the ancient Silk Road (Kuzmina, 2008; Baumer, 2016b) which connected early Chinese dynasties with the western parts of Asia, and later with the Antic and mediaeval Europe. Conversely, rubies and sapphires from India and Sri Lanka were brought to central Asia, including the area occupied by present-day Kazakhstan. Precious stones, some presumably of central Asian origin, were described in works from the Antique and Middle Ages, such as "Natural History" by the Roman naturalist Gaius Plinius Secundus (23-79 AD) or the "Collection of Information for Cognition of Valuables" of the Arab historian AlBiruni (973-1048 AD), respectively (Stone, 2004). Gems, including ruby, topaz, garnets, chalcedony, turquoise and rock crystal, among others, set up in 
gold plaques and other votive ornaments were part of rich burial offerings of the Scythian-Saks' and Sarmat early Iron Age $\left(8^{\text {th }}-2^{\text {nd }}\right.$ centuries BC) kurgan complexes and the historical Hun $\left(2^{\text {nd }}-5^{\text {th }}\right.$ century AD) ceremonial sites located on the territory of eastern Kazakhstan and the neighbouring Gorno Altay (Ukok) and Almaty regions (Akishev, 1978; Polosmak, 2001; Kim, 2002; Kuzmina, 2007; Samashev, 2011, 2014; Parzinger, 2017). These compete with the most opulent Iron Age Scythian (Pazyryk Culture) graves in Tuva, Siberia (Gryaznov, 1980; Chugunov et al., 2003) and the Sarmat sites in the southern Urals (Gutsalov, 2007).

Locally occurring gemstones received regular attention following the Russian annexation of these territories by the Moscow-ruled Tsar Empire during the $17^{\text {th }}$ and $18^{\text {th }}$ centuries (Christian, 2018). At that time, present-day eastern Kazakhstan was the southernmost part of the West Siberian Tomsk Gubernia (administrative district) of the Russian Empire. The Rudno Altay jasper in particular (in addition to other gemstone varieties) became widely renowned (Sokolev \& Bulgak, 1981) (Fig. 10C). The first information on cut coloured stones of the Altay region dates back to the $18^{\text {th }}$ century (Mukaeva, 2011). The local lapidary production and gemstone business was concentrated in the Loktevskaya stone polishing factory. In 1802, another, newly established (by the Demidov Russian dynasty of entrepreneurs) factory, the Kolyvanskaya, became the centre in the processing of diverse precious stones obtained from regional exploitations. Other workplaces aimed at gemstone working, including opals from the Nikolayevskoye mine and amethysts from both the Solomonovskoye and Mikhailovskoye mines. Artistic products, including cut and polished precious gems manufactured from Altay minerals, were presented and highly regarded on international exhibitions at London in 1851 and 1862. Natural stones of the Altay origin are also on display at Versailles palace (Gusev, 2007). The role of the exploited coloured stone deposits was crucial for the production of jewellery and decorative art along with stones from the Ural Mountains; this also contributed to scientific and technical progress at the time (Mukaeva, 2008). In their broad natural varieties, gemstones of present-day eastern Kazakhstan became most famous for their beauty (Fig. 10A, B), such as the Rudno Altay jaspers reported by A.E. Fersman in the 1920 monograph "The Precious and Coloured Stones of Russia", in reference to the Palevoye and Ridderskaya breccia deposits.

Modern systematic mapping of the geological deposits that yield gemstones in eastern Kazakhstan dates back to the 1960s (Grigorovich et al.,
1990). In 1971-1973, geological exploration by the East Kazakhstan Technical Institute led to the discovery of many new mineral bodies. At that time, fieldwork focused on locating occurrences of ornamental chalcedony, jasper, quartz and other gemstones of aesthetic appearance. A prospection-oriented reconnaissance survey was undertaken for non-metallic raw materials in the Charskiy zone as a part of the Geological Expedition no. 113 (Pacekov et al., 1990). This period was also the most productive time in the research of mineral deposits in Kazakhstan, with mapping of new geological sites of gemstone distribution (Kievlenko, 1980, 1989). A slowdown in exploration during the 1980s preceded the dramatic economic drop in the 1990s after the breakdown of the Soviet Union, which de facto led to the abandonment of almost all former exploratory and processing work related to the previously active precious and decorative stone exploitation on the territory of eastern Kazakhstan. These activities have in part been re-established, but only in recent years by means of both national and private foreign investments as well as by implementation of new exploratory/processing techniques.

The present study provides an illustrated overview of the principal and most characteristic gemstone varieties from East Kazakhstan region, their specific geographical and contextual geological distribution and current application. The area under discussion is of major importance for scientific knowledge of specific non-metallic mineral resource occurrences in central Asia. The present paper offers an insight into current and perspective gemstone resources and their practical use from a cultural-historical perspective.

\section{Geography and geology of the study area}

The area discussed is located in the northern and eastern parts of the East Kazakhstan region, being bordered by mountain massifs in the north and east and opening into flat steppes and semi-deserts in the west and south (Fig. 1A). Geomorphologically, the broader territory is highly diverse, reflecting the complex regional orographical structure that is subdivided into several mountainous regions, i.e., the central Altay (Katunskyy, Listviaga, Eastern and Chindagatuy ranges), the southern Altay (Tarbagatay, Sarymsakty, Narym, Kurchum and Azutay ranges, Kalbinskiye/Kalba Mountains), the northwestern Altay (northwestern Listviaga, Kholzun, Tigiretskiy and Ivanovskiy ranges; Aleyskie, Ubins- 
kiye, Ul'binskiye and Bukhtarminskiye mountains) (Grigoriev, 1950; Nekhoroshev, 1967; Chupakhin, 1968; Ren, 2013; Dyachkov et al., 2014a).The principal gem-bearing localities are shown in Figure 2.

The key physiogeographical unit associated with occurrences of decorative and precious stones is the Kalba Range (Fig. 2C, D), which represents a continuation of the low-elevation mountain massifs of the southern Altay (Fig. 2E) (Velikovskaya, 1946; Muratov \& Slavin, 1953). This extends on the left side of the Irtysh Basin northwards to the city of Ust'-Kamenogorsk, the regional administrative

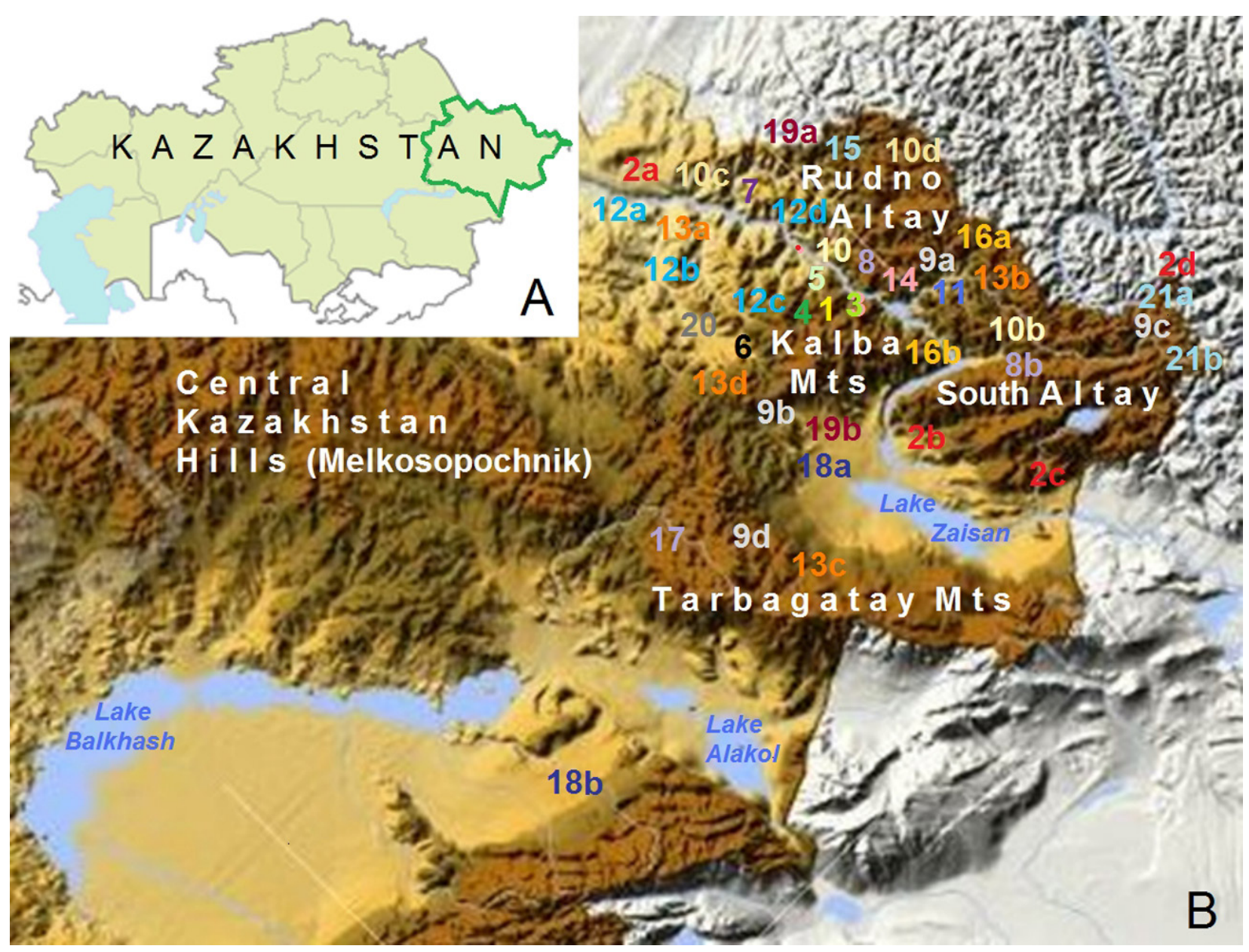

Fig. 1. A - Study area; B - Territory of eastern Kazakhstan with geographical distribution of precious, semi-precious and decorative stone deposits discussed in the present study. 1 - Topaz (Gromovskoye, Kalba Formation, Ulansk District); 2 - Ruby: 2a (Primarkokolye, Uspenka District), 2b (River Kurchum, Kurchum District), 2c (rivers Kaldjir and Bala-Kaldjir, Kurchum District), 2d (North Belukhinsk, Gorno Altay); - Coloured tourmaline and rubellite (Beacon and Asubulak, Kalba Formation, Ulansk District), 4 - Emerald (Nikolaevka, Kalba Formation); 5 - Beryl (Del'begetey, Kalba Formation); 6 - Diamond (Gromovka and Maloye Karasy, Del'begetey, Kalba Formation, Ulansk District); 7 - Garnet (Shemonaikha District, Rudno Altay); 8 - Kuntzite: 8a (Glubokoye District, Rudno Altay), 8b (Kalba-Narym zone); 9 - Rock crystal quartz: 9a (Savushinsk and Tigerek Formation, Rudno Altay), 9b (Akyailau, Dungali and Biesimas, Kalba and Zharma-Saur formations), 9c (Arshaty, Katon-Karagay District, southern Altay), 9d (Akzhayliau, Zharma-Saur Formation); 10 - Quartz: 10a (Targin and Samsonovka, Rudno Altay), 10b (Karaozek, Rudno Altay), 10c (Piezokvartsevoye, Pri-Irtyshiye), 10d (Prokhodnoy Belok, Rudno Altay); 11 - Turquoise (Zyryanovsk, Rudno Altay); 12 - Chrysoprase: 12a (Semipalatinskoye Pri-Irtyshiye), 12b (Kyzylchar, Ulansk District), 12c (Belogorskiy-Chernikhiv, Kalba Formation, Ulansk District), 12d (Glubokoye District, Rudno Altay); 13 - Agate/ chalcedony: 13a (Del'begetey, Ulansk District), 13b (Aliyan, Rudno Altay), 13c (Manrak, Saure and Saikan, Zharma-Saur Formation, Tarbagatay Mountains), 13d (Maloye Karasy, Kalba Formation); 14 - Rhodonite (Chekmar, Rudno Altay); 15 - Labradorite (Beloulbinsk, Ridder District, Rudno Altay); 16 - Jasper: 16a (Ridder-Sokol'noye, Ridder District, Rudno Altay), 16b (Kalba Formation); 17 Amethyst - Solomonovskoye deposit (Chingiz-Tarbagatay Formation); 18 - Fluorite: 18a (Kalba Formation), 18b (Karadzhal deposit, Almaty Region); 19 - Granite: 19a (Rudno Altay), 19b (Kalba Formation); 20 - Marble/marbled limestone (Novo-Taubinskoye, Kalba Formation); 21 - nephrite: 21a (Koksu River), 21b (upper Bukhtarma River) 

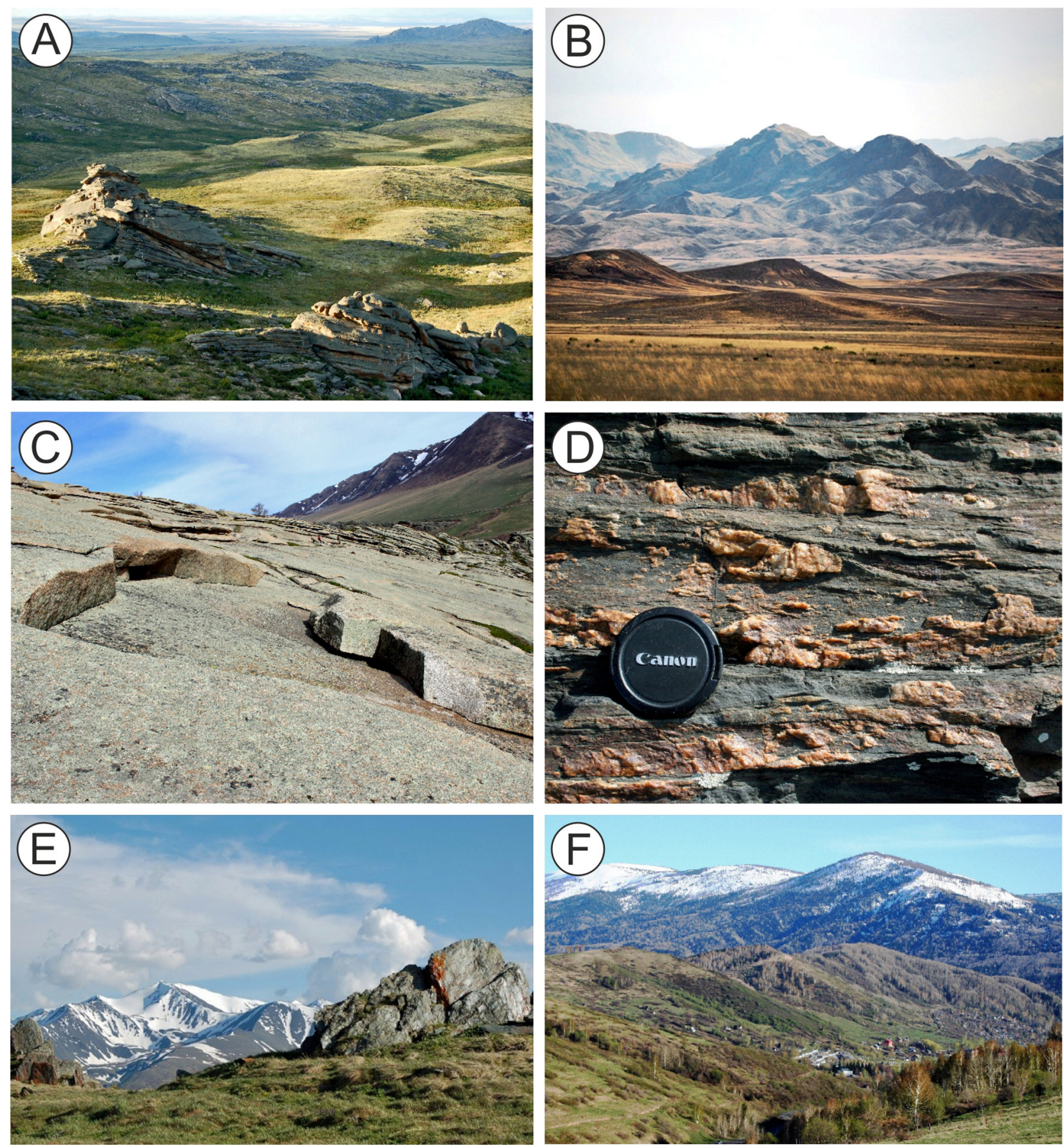

Fig. 2. Structural relief in eastern Kazakhstan predisposes rich occurrences of a variety of gemstones in orogenic and metamorphic, as well as secondary sedimentary formations

A - central Kazakh "melkosopochnik", the low-elevation, hilly ultramafic granitic plateau (700-800 m asl.), separated by shallow continental depressions; B - Tarbagatay Mountains (1,500-3,000 m asl.), incorporating the Yarma/Zharma-Saur gemstone-bearing formation; C - Kalba Mountains (500-1,600 m asl.) linked to neo-tectonics and characterised by an "onion" shaped top-surface-weathered granite structure; D - Kalba Formation, consisting largely of interbedded granitic-gneissic layers hosting pockets and veins of decorative minerals (Del'begetey Formation), representing one of the most opulent gemstone and decorative stone localities in the country; $\mathbf{E}-$ south Altay Mountains (2,000-4,000 m asl.) structured by igneous and metamorphic rocks (mainly granites, granodiorites, quartz-diorites and gneiss) including, in places, semi-precious minerals; F - Rudno Altay Mountains (1,200-2,000 m asl.), historically known for the most prolific and mineralogically diverse gemstone occurrences (Ridder-Sokol'noye Formation). For specific gemstone distribution, see Figure 1. Photographs by the author 
and economic centre. The eastern part of the S-N oriented hills is characterised by a lower- and midrange topographic structure of $c$. 700-1,300 $\mathrm{m}$ asl, reaching elevations up to 1,400-1,600 $\mathrm{m}$ asl along the principal (eastern/western) water divides. The high relief differentiation of the Kalba Range generates local microclimate conditions, reflecting the topographic configuration of the massif (Chupakhin, 1968; Dyachkov et al., 2014b). This eastern part of the country is very rich in natural resources, including precious metals ( $\mathrm{Au}, \mathrm{Ag}, \mathrm{Pt})$ and other minerals (Mitrayeva, 1990; Pacekov et al., 1990). Outcrops are associated with mafic igneous and metamorphic rock bodies that are distributed along the main regional structural zones of neotectonically uplifted crust (Martinovskiy, 2003; Gusev, 2010) and host the principal gemstone and coloured stone occurrences in the region (Dyachkov et al., 1996).

The topographic relief of eastern Kazakhstan testifies to geologically more recent, active and still continuing tectonic processes following former stages of relative geological stability with periodic pre-Cenozoic sea basin existence, filling continental depressions of the present study area (Veselova, 1970). Intensified tectonics that led to a more pronounced regional physiographic development is associated with Lower Palaeozoic (Caledonian) and Upper Palaeozoic (Hercynian) uplift (Schulz, 1948). Fracturing of uplifted continental plates generated a complex system of elevated plateaus separated by depressions and small rifts along E-W aligned tectonic faults (Erofeev, 1969). Subsequent tectonic activity caused a regressive retreat of marine basins and led to the generation of uplifted masses of the present Tarbagatay, Kalba and Southern Altay ranges that are expanded in a southeasterly direction (Muratov \& Slavin, 1953). Massive coarsely clastic conglomerates and sandy-gravel deposits from the dividing intermountain depressions are proof of large-scale Pliocene to sub-recent erosional processes of rising relief along the margin of the Zaisan Basin (Kravchenko et al., 1974; Chlachula, 2010).

The formation of the Kalba Range and the adjoining Tarbagatay Range was completed by the Late Palaeozoic (Variscan) orogeny (Fig. 2B). The majority of the former uplifted continental territory was completely denudated subsequently during the Mesozoic. The neotectonic phase at the Neogene/ Quaternary boundary triggered the formation of the present-day Altay Mountains with adjoining ranges including the youngest orogenic bodies (Velikovskaya, 1947). Typical geomorphic features of the Kalba Range Highlands include broad and low-elevated erosional granitic plateaus separated by deep valleys and shallow depressions contrasting with the high Alpine relief of the Altay. The topographic elevations were subjected to long-term weathering processes and sculpted into exposed, vegetation-free rocky granitic hills (Obruchev, 1951). The average altitude range is $700-750 \mathrm{~m}$ asl, being cut by a series of south-trending erosional relief features. The intermountain depressions are filled by denudated gravity-slope sediments of diverse structures and compositions depending on the depositional geo-settings. The eastern parts of the mountains are more rugged compared to the smoother western side. The northern slopes are rather steep, unlike the southern ones that gradually merge into undulating open steppe landscapes of the Zaisan Depression. The western part of the Kalba Range (i.e., the interflow drainage area between the Bukhtarma and Narym rivers) is differentiated by a more physiographically marked relief shaped into steep rocky peaks and small hills (Fig. 2A). Along the southern margin, there are low-relief plains with chains of exposed, low-elevation rocky hills ("mel'kosopochniki") that extend further west into central Kazakhstan.

The regional geology reflects the dominant tectonic origin of the area of eastern Kazakhstan that structurally is constituted by parallel NW-SE oriented ranges of the uplifted Alpine massifs of the Chingiz-Tarbagatay (Fig. 2B) and Gorno Altay, separated by the tectonic graben/suture zone that forms the present Zaisan Basin (Fig. 1B). The transitional relief is represented by the Zharma-Saur and Rudno Altay, respectively (Fig. 2F). The corresponding key units are illustrated in Figure 3. A low-grade regional metamorphism of pelitic sedimentary rocks, following the Lower Palaeozoic granite intrusions with chlorite-muscovite shales, sericite-chlorite shales, metatuffs and metadrobes characterises the area. The volcanites are high-acidity granites; leukocratic varieties prevail. Coarsegrained alkaline granites predominate in the easternmost border zone of the southern Altay.

\section{Material and methods}

The gemstone (coloured and decorative stones) collections of the Mineralogy Museum of the East Kazakhstan State Technical University, UstKamenogorsk (EKSTU), were used for the present study. These were supplemented by newly assembled material during personal fieldwork between 2005 and 2015 in eastern Kazakhstan (Chlachula \& Selyanina, 2007; Simcikova, 2007), including mapping of the principal gemstone-bearing formations. Standard petrological and mineralogical analyses of gemstones and decorative stones, comprising 
around 150 samples completed by 75 single gemstone exemplars from the EKSTU Mineralogy Museum collections, were done at EKSTU (Department of Ore Geology and Mineralogy) and at Adam Mickiewicz University (Institute of Geology, Poznań).

The laboratory treatment of stored and newly collected lithic materials included a selection of mono-mineral fractions and preparation of polished slabs and thin sections of the samples studied for SEM analysis of the mineralogy. Energy-dispersive X-ray spectroscopy (EDX) was performed by using a low-vacuum emission electron microscope JEOL (JSM - 6390 LV) with non-conductive samples coated by a thin layer of gold. For elimination of geochemical anomalies and exposure of elements/ indicators of the specific ore-forming processes, a mass-spectrometer with inductively coupled plasma (JCP-MS Agilent, 7500x), with a standard definition of 73 elements, was used to provide geochemical and metallogenic characteristics of host magmatic bodies (EKSTU, AMU). Determination of the crystalline structure of specific gemstones and selected minerals/rocks with element concentrations was performed by using a CPB-1M X-ray spectrometer. The aim of the laboratory investigations was to obtain chemical and gemmological characteristics of gemstones analysed and of their host rock units in the area studied, and to test new methods for making prognoses for perspective places and geological formations with gemstone occurrences (Chernenko et al., 2012; Chernenko \& Chlachula, 2017).

For contextual studies at superficial gemstone-bearing sites, GPS-localised rock samples were taken in the field, largely from the area of the southern Altay (Fig. 1B) and documented by photography. Selected samples (50) were subjected to a detailed microscopic mineralogical study using polished sections and EDX point analysis (performed on a Cam Scan S4 device with Link ISIS 300 analyser). Microscopic observation in transmitted light with photographs included structural features of rock samples, representation of rock-forming minerals, accessories and textural features. The preparatory work consisted of a study of the scientific (mostly Soviet and more recent Russian) literature and of regional geological maps of the Kazakh Altay.

\section{Gemstone occurrences in eastern Kazakhstan: an overview}

On the territory of eastern Kazakhstan, there are several highly interesting varieties of precious and

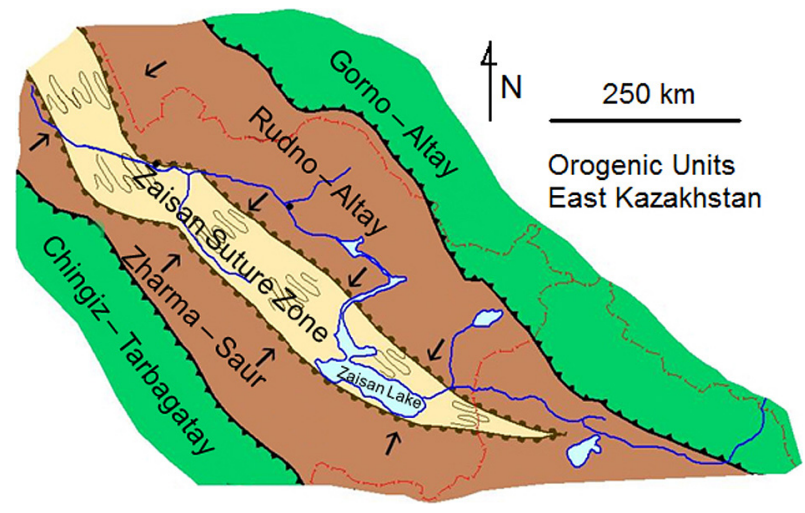

Fig. 3. The principal structural orogenic units hosting gemstone deposits in eastern Kazakhstan: the Chingiz-Tarbagatay (1,500-3,000 $\mathrm{m}$ asl.) and Gorno Altay $(2,000-4,500 \mathrm{~m}$ asl.) orogenic zones descending through the Zharma-Saur (500-1,500 m asl.) and Rudno Altay (1,000-2,000 $\mathrm{m}$ asl.), respectively, into the Zaisan depression suture zone (300-500 m asl.) drained towards the northwest by the River Irtysh (courtesy of Z. Chernenko, with modification by the author)

decorative stones (Kravchenko et al., 1974; Smith, 1980; Scherba et al., 2000; Chernenko, 2007, 2011). The distribution of gemstone-bearing deposits here (Fig. 1B) corroborates the regional geological structure of the Altay-Chingis-Tarbagatay orogenic units (Fig. 3). The best-mapped and mineralogically most prolific rock mineral and metallogenic bodies of the West-Kalbinskaya and the Charsko-Zimunaiskaya suture zones of Palaeozoic granites, granodiorites and quartz diorites in particular are known for occurrences of diverse, high-quality gems. The following is a synopsis of the main and most relevant gemstones, both crystalline and cryptocrystalline, that originate from this mineralogically still marginally known part of central Asia and have both major scientific importance and traditional decorative applications.

\subsection{Topaz}

Topaz (known since Antiquity) has a long tradition in eastern Kazakhstan and adjacent regions. This precious stone is recorded at the Altay archaeological sites dating back to prehistoric and early historical times in connection with early Iron Age $\left(5^{\text {th }}-2^{\text {nd }}\right.$ centuries BC) Scythian and Hunno-Sarmatian civilisations (Vdovina, 2001). Due to their hardness, topaz crystals are also considered to be excellent gemstone material, for their brilliance and colour range. Documented occurrences in eastern Kazakhstan include a unique (topaz and aquamarine) site in the western part of the Kalba Mountains, 9 
$\mathrm{km}$ northwest of the village of Gromovka, in the southern zone of the Del'begetey granite formation (Gromovskoye deposit) (Fig. 1B: 1). At that locality, topaz gem qualities are associated with extensive greisenization zones of granites (quartz-muscovite and quartz-topaz mineral associations) that extend spatially for about $300 \mathrm{~m}$ and reach a thickness of 10-15 m. The gemstones occasionally occur in rare metal deposits as aluminium-sodium silicate [Al$\left.{ }_{2} \mathrm{SiO}_{4}\left(\mathrm{~F}, \mathrm{OH}_{2}\right)\right]$ with a common quantitative chemical composition of $\mathrm{Al}_{2} \mathrm{O}_{3}$ (48-62 wt.\%), $\mathrm{SiO}_{2}$ (28-39 wt.\%), F (13-20 wt.\%), $\mathrm{H}_{2} \mathrm{O}$ (1-2 wt.\%), comparable to ultra-acidic mineral occurrences in the ore-magmatic fields of southern Altay (Sokolova et al., 2011). Crystals of topaz and beryl found in micro-lithic nests are subject to current prospection.

The gemstones are characterised by crystals of elongated prismatic and isometric shapes of high-purity with luminous verges. Colourless crystals predominate; rarely, bluish or yellowish varieties occur. Topaz is found as small (3-5 mm) transparent crystals enclosed in crystalline cavities. The accompanying aquamarine is mainly pale blue, occasionally deeply dyed, forming crystals of 6-15 mm in size. Frequently, the gemstones display transverse superficial cracks and are not fit for jewellery processing.

\subsection{Corundum (Ruby/Sapphire)}

Rubies and sapphires as specific varieties of corundum $\left[\mathrm{Al}_{2} \mathrm{O}_{3}\right]$ are precious gemstones of the mountainous area of eastern Kazakhstan. Red-coloured rubies are known from the well-known Uspenskiy deposit (Fig. 1B: 2a). The first find of a high-quality ruby was made in the village of Primarkokolye (Uspenka District) in 1992: a dark red ruby crystal of $0.6-1.0 \mathrm{~cm}$ in size and of gem quality. This particular find initiated mapping of other occurrences. All specimens of ruby studied (chemically uniformly characterised by c. Al 53 wt. \% and $\mathrm{O}_{2} 47$ wt.\%), originate from within the limits (contact zones) of Proterozoic metamorphic rocks-kyanite gneisses, migmatites and amphibolites (Chernenko, 2007). The occurrence of blue, pink and colourless sapphire was documented on the right bank of the River Kurchum in the south-east of the territory (Fig. 1B: 2b). A blue sapphire deposit with single gem crystals of up to $0.7 \mathrm{~cm}$ in length has recently been detected between the Kaldjir and Bala-Kaldjir rivers, tributaries of the River Black Irtysh (Fig. 1B: 2c). The local quality corundum attracts mich attention and is subject of ongoing exploratory works.
Another ruby occurrence is known from $3 \mathrm{~km}$ north of the Belukha Mountains (North Belukhinsk site) (Fig. 1B: 2d), is bound to high-aluminium crystalline schists and gneisses of the Southern Chua metamorphic complex. The ruby is noted in cuts with kyanite, silliamnite and garnet, occurring as transparent, dark red-coloured crystals of up to 3-5 $\mathrm{cm}$ in size (Gusev, 2020).

\subsection{Beryl}

Beryl is one of the most precious gemstones of eastern Kazakhstan, consisting mineralogically of beryllium-aluminium cyclosilicates $\left[\mathrm{Be}_{3} \mathrm{Al}_{2}\left(\mathrm{Si}_{6} \mathrm{O}_{18}\right)\right]$. Beryl and its emerald and aquamarine varieties of greenish and bluish colours, respectively, have all been recorded from the Del'begetey mineral-bearing deposit (Dyachkov et al., 1998; Gavrilenko et al., 2006) (Fig. 1B: 5). This is represented by transparent prismatic crystals of pale green to greyish green colours and sizes of up to $1.5 \mathrm{~cm}$. The host rock is placed in the middle part of the zonal column (at the level of greisenization and silicification) that was discovered by A.G. Alekseyev in 1969. In the tectonic zone of the northwestern part of the formation, an intensive boron-fluorine-beryllium mineralisation occurred in the greisens and quartz veins. This is presented in the form of concentrated nests and veins of quartz-tourmaline-fluorite-beryl compositions with a variable size of gemstone crystals of narrow, elongated shapes (0.1-1.0 $\mathrm{mm} \mathrm{x}$ 2-5/10-15 mm). The principal beryl concentrations are found in the contact zones crossing with granite dykes. Analogous beryl minerals are known from the neighbouring Chinese Altay (Wang et al., 1994).

The distribution of emeralds (green Cr-beryl), mapped in the northeastern part of eastern Kazakhstan, is geographically rather restricted. These precious stones occur largely in secondary position in alluvial sediments in the upper and middle reaches of the River Nikolayevka River that drains into the River Suikbulak (Fig. 1B: 4). The initial search for these gems, in Russian referred to as izumruds, was carried out at the eponymous site Izumrudnoye in the Charsko-Zimunaiskoy zone by A.Y. Dolbin and N.P. Michailov in 1947-1948. A systematic emerald prospection in the original ultramafic formations was initiated in the early 1980s. Mineralisations are presented by small $(0.1-2.0 \mathrm{ct})$ crystals, their fragments or small clasts (pebbles) of different shades of green. The ultramafic rocks host $0.3-0.5-\mathrm{cm}$-large crystals of yellow, yellow-green to green colour (Fig. 4A), whereas emerald-like gem-quality olivine (peridot) from the intrusive peridotite igneous for- 

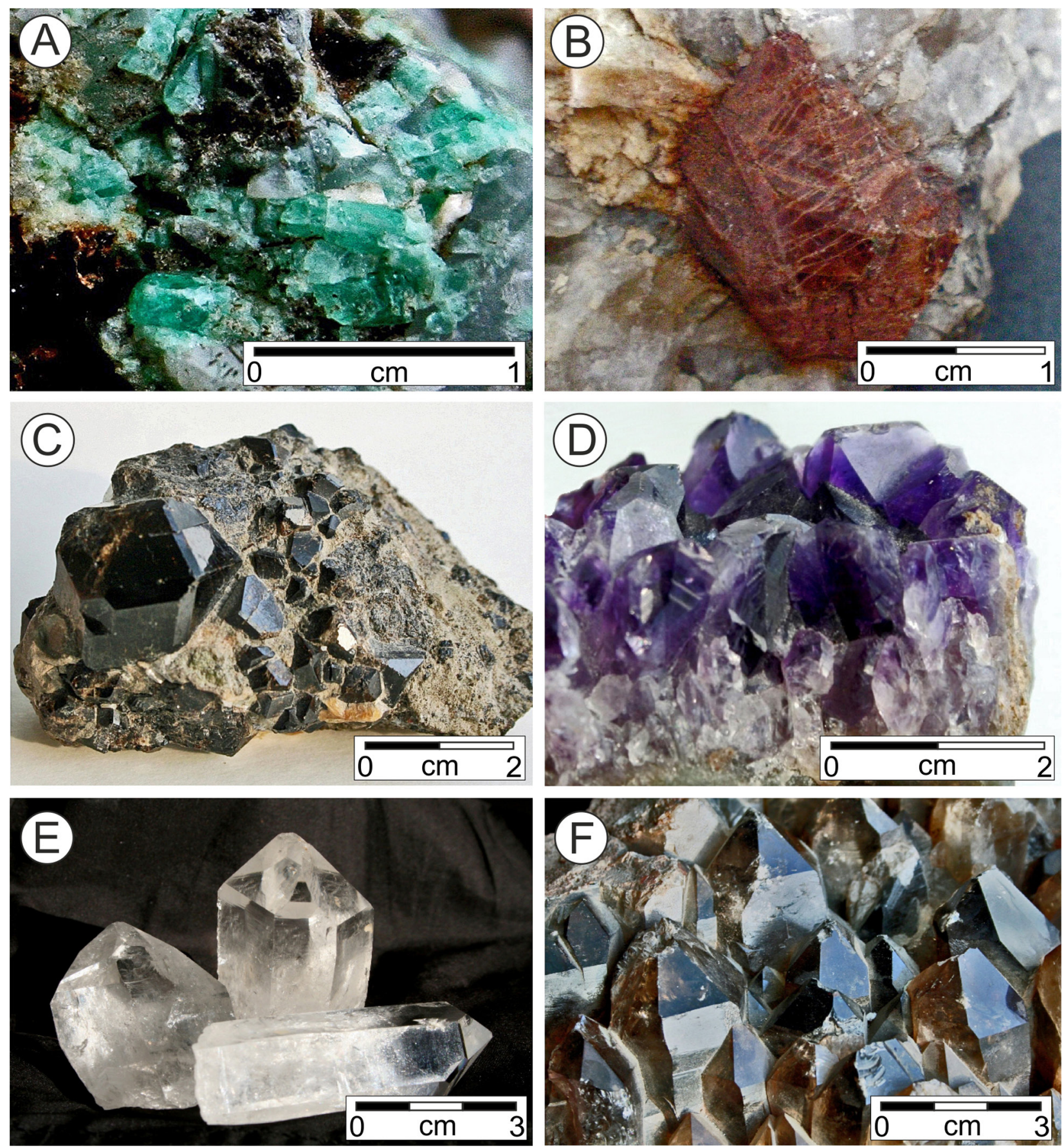

Fig. 4. Gemstones of eastern Kazakhstan

A - Emerald (Izumrudskoye deposit, Kalba Mountains); B - Rubellite (Asubulak deposit, Kalba Mountains); C Garnet (western Rudno Altay); D - Amethyst (Solomonovskoye deposit, Tarbagatay Mountains); E - Rock crystal (Arshaty, southern Altay); F - Smoky quartz (Akyailau deposit, Zharma - Saur Formation, Tarbagatay Mountains). Mineralogy Museum EKSTU (A-D, F); author's collection (E)

mations accommodate flatter, grey-coloured variants. The estimated contents of emerald crystals in the enclosing ultramafic rocks are $4.5-13.6 \mathrm{ct} / \mathrm{t}$; in picrites (high-magnesium olivine basalt) $6-12 \mathrm{ct} / \mathrm{t}$. The green beryl gemstones of eastern Kazakhstan (the Del'begetey deposit) (Fig. 1B: 5) are character- ised by very small concentrations of impurities ( $\mathrm{Fe}$, $\mathrm{Mg}$, Na) (Gavrilenko et al., 2006). In sedimentary alluvial placers, some individual larger (up to 1 $\mathrm{cm}$ ) and high-quality emeralds can occasionally be found. Nearby emerald-bearing localities of Gorno Altay associated with quartz veins are found in the 
Kalguty valley (Sementsov, 2004), with crystal sizes along the long axes reaching $1.5 \mathrm{~cm}$, and up to $3 \mathrm{~cm}$ in alluvial deposits of the upper valley of the River Narym (Gusev, 2007).

\subsection{Diamonds}

There are some economically insignificant distributions of diamonds in eastern Kazakh ultramafic volcanic bodies (Chernenko, 2007). There is a diamond deposit in the district of the villages of Gromovka and Karasy, within the southern part of the Del'begetey granite multiphase zone (P2) with biotite-hornblende granosyenites, biotite granites and leucocratic granites (Fig. 1B: 6). These diamonds are usually of smaller size ( $<1$ carat) with frequent impurities and undesirable darker colouring of crystals predetermining their exclusively industrial use. Yet, some potential of locating the original magmatism-linked kimberlitic-lamproite series of a higher (jeweller) quality of natural crystals cannot be ruled out. Currently known concentrations of quality diamonds in the plutonic ultramafic formations are rather low. The local diamonds are assumed to be the result of corrosion and erosion in the process of the bedrock weathering and secondary sedimentary transfer. Diamond prospection for jewellery application is currently not undertaken in eastern Kazakhstan (or anywhere else in the country). The reported minor diamond occurrences in the area of Lake Teleckoye (Gorno Altay) are bound to the local kimberlitic dykes (A.I. Gusev, pers. communication, 2020).

\subsection{Garnets}

The main garnet occurrences are situated in the western part of the Rudno Altay with minor localities in the Kalba Mountains (Fig. 1B: 7). The local garnets with analytic silicate-magnesium-aluminium chemical composition $\left(\mathrm{SiO}_{2} 45\right.$ wt. \%, $\mathrm{MgO} 29$ wt.\%, $\mathrm{Al}_{2} \mathrm{O}_{3} 25$ wt.\%) are known from the mineralogically most significant Del'begetey Formation in the polymetallic and rare metal deposits. There, this group of silicate minerals occurs in the form of small- to medium-sized $(0.2-1.0 \mathrm{~cm}) \mathrm{m}$ regular opaque crystals mostly of almandine $\left(\mathrm{Fe}_{3} \mathrm{Al}_{2}\left[\mathrm{SiO}_{4}\right]_{3}\right)$ and pyrope $\left(\mathrm{Mg}_{3} \mathrm{Al}_{2}\left[\mathrm{SiO}_{4}\right]_{3}\right)$ type. They are characterised by dark red to reddish-black colours with a prominent lustre. Another garnet site is found in the Kurchum District (Karchiga Deposit; see Lobanov \& Gaskov, 2012). The quality and larger (up to $3 \mathrm{~cm}$ ) size of raw crystals (Fig. 4C) predetermine their use in jewellery. Quality garnets, together with other precious stones such as beryl and tourmaline, are found in the neighbouring Chinese Altay in zonal granitic pegmatite formations alongside contacts with schist and gneiss bodies (Keller \& Fuquan, 1986).

\subsection{Kuntzite}

Kunzite is a crystalline lithium-aluminium silicate mineral $\left[\mathrm{LiAl}\left(\mathrm{Si}_{2} \mathrm{O}_{6}\right)\right]$ of the clinopyroxene group (Klein \& Dutrow, 2007; Manutchehr-Danai, 2010; CIBJO, 2012). The good-quality eastern Kazakh stones are used for jewel processing mostly in the form of easy-to-cut, emerald-shape facetted gems up to $1 \mathrm{~cm}$ in size. Within the close geographical area, this rare mineral is represented by translucent light pinkish to pale violet variants of small (3-5 $\mathrm{mm})$, single crystals enclosed in veins of spodumene crystalline series of the Rudno Altay and in the Kalba-Narym zone (Beacon deposit) (Fig. 1B: 8). A geographically close distribution in pegmatite veins of granitoid porphyry is known from the neighbouring Gorno Altay (Alakhinsk site) which produces large (up to 1-2 cm), high-quality rose-coloured crystals (Gusev, 2007, 2020).

\subsection{Quartz}

Quartz is widely distributed in eastern Kazakhstan in different spectral varieties and of diverse quality. This mineral is bound to primary (crystalline/metamorphic) ore formations, but is also broadly present in secondary sedimentary deposits (alluvial gravels), having been accumulated by rapid-flowing mountain streams. Occurrences of high-quality quartz have been mapped in the zone of Karagoin-Sariozek (Targin, Bailer, Samsonovka and Karaozek areas; Fig. 1B: 10a-b). Pink and white-coloured variants (Fig. 9A, B) appear in the form of veins and kernel in pegmatites or granites of the Rudno Altay and the Kalbinskiy Complex P1. The local quartz facies have a semi-lucent to translucent, massive or striped texture due to bismuth; chlorine and iron hydroxides impact this particular colouring. Some quartz crystals reach sizes of up to c. $5 \times 5 \times 10 \mathrm{~cm}$.

The principal deposit of fine-grained gemstone quartz is located $2 \mathrm{~km}$ from the village of Targin, where the local quartz formation is represented by pegmatitic veins that extend laterally for over 50-180 m, forming a lentiform body of a thickness of 1.7-12.0 m. Crystalline kernels show 1-2 
$m$ wide cracks consisting of white, pink and grey quartz masses. The estimated rock supplies for industrial purposes are 1,500 tonnes (Z. Chernenko, pers. communication, 2016). Other key sites with superior, fine-crystal stone quality are found at Piezokvartsevoye, in the northern Pri-Irtyshiye area and at ProkhodnoyBelok in Rudno Altay (Fig. 1B: 10c, d).

Very attractive, clear and perfectly transparent rock crystals have been known since the $18^{\text {th }}$ century, with the principal locality situated on the left bank of the River Irtysh (Fig. 1B: 9). Over 200 representative samples are on display in the mineralogy collections of the East Kazakhstan Technical University with crystals measuring up to $20 \mathrm{~cm}$ in length. Genetically, all samples belong to the pegmatitic and hydrothermal (quartz-veins) group. The local eastern Kazakh crystal quartz-hosting deposits are best developed in the Sirektas-Sarsazan-Kobukskaya zone of the Zharma-Saur Formation (Akyailau, Biesimas and some other sites), in the northwestern Kalba Range (Kalba Formations) and the Savushinskiy and Tigerekskiy granite formations of the Rudno Altay (Fig. 1B: 9a). Isolated mineral occurrences have been documented in the southern Altay area, as well as at some other places. In the border zone area of the upper Bukhtarma Valley (east of village Arshaty), quartz crystals of up to 10 $\mathrm{cm}$ in size occur in local bedrock cavities.

The deposit of Akyailau is located $78 \mathrm{~km}$ east of the village of Ayaguz within the limits of a Permian granite formation which includes four pegmatitic fields: a northwestern, a central, a northeastern and a southern. The main gemstone-bearing body is represented by crystalline pegmatites of lentiform shapes $(12 \times 8 \mathrm{~m}$ or larger), following to a depth of 6-10 $\mathrm{m}$ and being characterised by a clear zonal structure. The external part builds a graphic pegmatite placed to the centre of pegmatitic quartz by block zones and a quartz kernel. The thickness of the quartz kernels varies from 1 to $5 \mathrm{~m}$. Local quartz crystals are on average $3.0 \times 0.5 \mathrm{~cm}$ in size, with incorporating pockets hosting individual brownish crystals up to $60 \times 20 \times 20 \mathrm{~cm}$ in size which is still minor in view of quartz crystals recorded from neighbouring Russia (Bukanov, 2011).

Another quartz deposit, Dungali, is found in the Kalba Massif (Fig. 1B: 9b). Chambers of crystal pegmatites here form lateral bands, $1.5-1.7 \mathrm{~km}$ long in the fractured sub-latitudinal crack zones of the host formation (Dyachkov et al., 2014b). Pegmatites are represented by small, isometric and lentiform bodies of a few metres in size of enclosing graphic structure at contacts of granite to quartz-microcline zones and quartz kernels. Rock cavities also include feldspar, fluorite (Figs. 1B: 18a; 5E) and quartz. Hydrothermal facies of rock crystals are widespread on the territory of Rudno Altay, and in the Kalba and the Zharma-Saur Mountain massifs. These are represented by quartz veins in sedimentary levels, volcano-sedimentary units and intrusions. The nature of the siliceous veins documents the intensity of the processes of metasomatism and recrystallisation of quartz. The size of the pockets varies from 0.5 to $1.0 \mathrm{~m}$. Inside these, prismatic forms of rock crystal, aquatic-transparent and semi-lucent variants occur. High-quality clear and smoke-coloured forms are known (Fig. 4E, F).

Amethyst as a violet variety of quartz, ranging from pinkish to purple colours, belongs to some of the oldest known gemstones that have been used since antiquity on the territory of central Asia. In eastern Kazakhstan, larger crystals of amethyst are very rare. Deep violet amethysts occur in the Chingizskiy ore deposit within quartz veins (the latter attaining lengths of $200 \mathrm{~m}$ and thicknesses of 20-30 $\mathrm{m}$ ) incorporated in Sirektas granites. This gemstone has been known from and industrially exploited in the region since the late $19^{\text {th }}$ century with the opening of the Michailovsky and Solomonovsky mines of the Chingiz-Tarbagatay formations in southern part of eastern Kazakhstan (Fig. 1B: 17), producing a bluish amethyst facies (Fig. 4D). The local crystals are characterised by bright light-violet colours, hexagonal shapes and sizes of up to $3 \mathrm{~cm}$. Identical gemstones are known from some archaeological sites of various (prehistoric - early historical) ages across the country (Vdovina, 2001), pointing to exploration and exploitation of the superficially exposed, gemstone bearing sites in ancient times. The variegated mineral is largely used for decorative and collection purposes.

\subsection{Coloured tourmalines}

As boron silicate gem-quality minerals with numerous colour varieties, tourmalines are valued for their decorative appearance. These rather exceptional eastern Kazakh gemstones, with a wide range of colours, are found in pegmatite deposits of the Kalba Range (Asubulak and Ognevsko-Bakennoye pegmatitic fields; Karagoin-Sariozek orezone and some other places). Tourmalines are usually concentrated in microcline-albite, albite and spodumene-albite facies of crystalline veins. In the Asubulak pegmatite field, tourmalines occur in the Bolshoy October Trench: the Karmenkus, Ungursay, Akkezen and other deposits. These pegmatites are of the rare tantal alkaline types $\left(\mathrm{SiO}_{2} 30-44\right.$ 

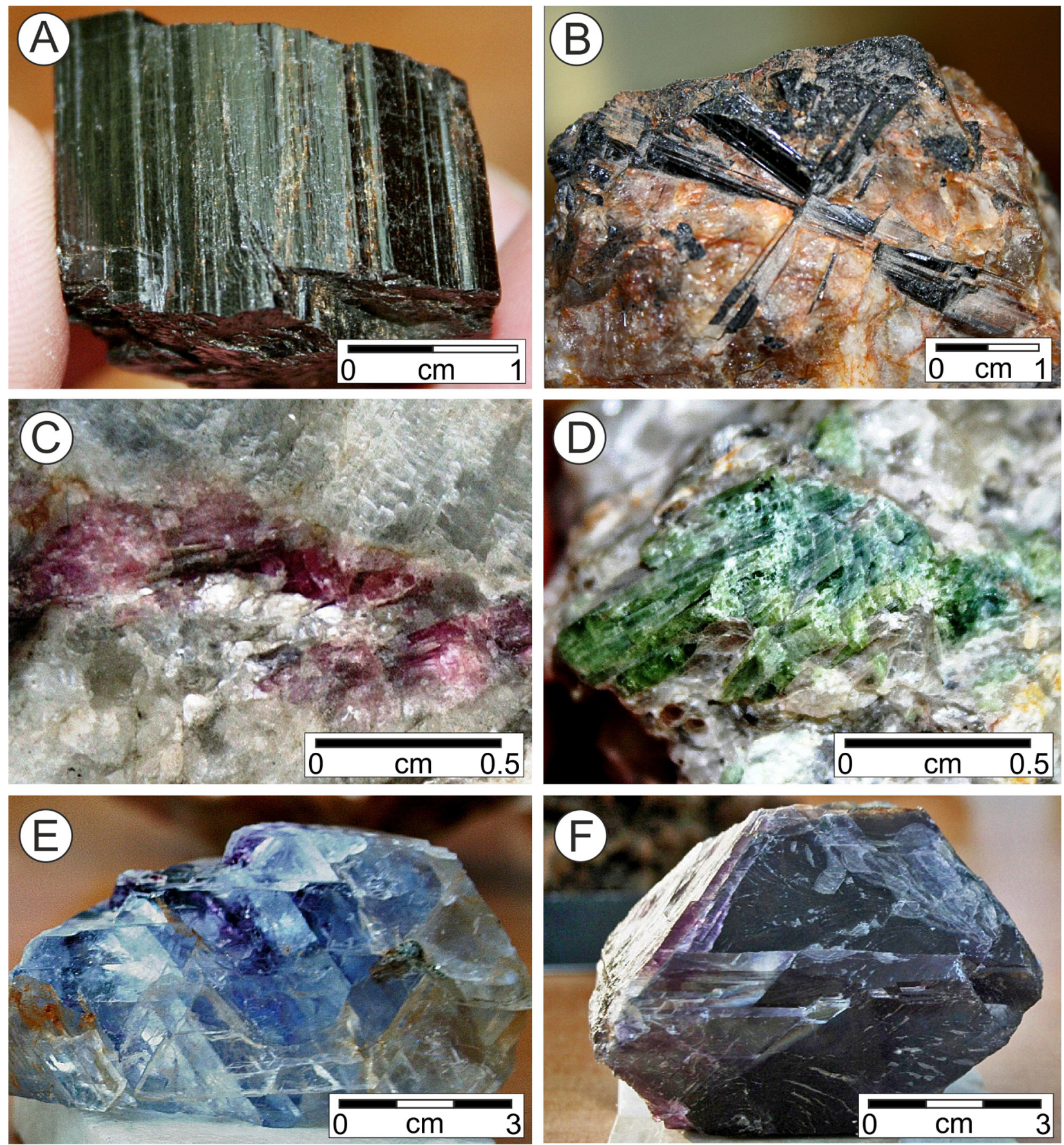

Fig. 5. Gemstones of eastern Kazakhstan

A-D - Coloured tourmaline (A-B, Yubileynoey deposit; C-D, Asubulak and Ognevsko-Bakennoe pegmatitic fields, Kalba Mountains); E-F - Fluorite (E - Kalba Formation, F - Karadzhal deposit, Almaty region). Mineralogy Museum EKSTU

wt. $\%, \mathrm{~B}_{2} \mathrm{O}_{3} 8-12$ wt. $\%, \mathrm{Al}_{2} \mathrm{O}_{3} 18-44$ wt. $\%, \mathrm{FeO}+\mathrm{Fe}_{2} \mathrm{O}_{3}$ 0-38 wt. \%, $\mathrm{MgO} 0-25$ wt. $\%, \mathrm{Na}_{2} \mathrm{O} 0-6$ wt. $\%, \mathrm{CaO}$ 0-4 wt. \%, $\mathrm{H}_{2} \mathrm{O} 1-4$ wt. \%).The use of these minerals is mostly collectionary rather than for jewel making.

The principal Akkezen tourmaline-bearing deposit in eastern Kazakhstan is situated in the central part of the Asubulakskiy pegmatitic field, within the Ungursaiskiy ore-bearing structure, where four large pegmatitic veins occur: the Main (with multi-coloured tourmalines), the Factory, the Large and the Middle (Chernenko, 2007). The first-named, or principal one (200 $\mathrm{m}$ in length and 3-7 $\mathrm{m}$ thick, with a southwesterly $30-80^{\circ}$ dip) has a microcline-albite structure. Tourmalines are represented by rubellite, 
verdelite, indicolite and other colour-zoned tourmaline varieties. In small ore cavities, tourmalines are found associated with smoky quartz (morion) crystals, pink quartz, Cl-bearing apatite, orthoclase and other minerals. In terms of quantity, in the gross bulk (75t) of raw geological material, there are coloured tourmaline crystals (c. $425 \mathrm{~g}$ in total), including transparent rubellite (red) and achroite (colourless) varieties (17g in total), semitransparent reddish-brown rubellite, blue indicolite and intensely green tourmalines (85g in total).

Another principal deposit, the Beacon Deposit, is found on the left bank of the River Irtysh, $3 \mathrm{~km}$ from Ognevka Hill in the vicinity of the eponymous village in the Ulansk District (Fig. 1B: 3). Here most of the coloured tourmalines originate from the "Spodumenovaya 1" vein (c. $200 \mathrm{~m}$ in length and 2-3 $\mathrm{m}$ in thickness). Gem-quality tourmalines (transparent and opaque rubellites, green verdelites and achroites) are associated in paragenesis with spodumene, lepidolite, pink quartz, rock crystal and morions. Opaque and variously coloured tourmalines predominate; crystals generally are smaller-sized, prismatic and c. $0.1-0.5 \mathrm{~cm}$ in diameter (Fig. 5C, D), but occasionally reach up to $2.5 \mathrm{~cm}$ (Fig. $5 \mathrm{~A})$. The approximate quantity of tourmaline in the mineral zone at a depth of $650-580 \mathrm{~m}$ is around 19 $\mathrm{kg}$. Industrial extraction of tourmalines is planned.

Rubellite, as a rare variety of tourmaline, is a highly valued gemstone, primarily in the red/pink variety of the elbaite group (Manutchehr-Danai, 2010). A specific multi-facetted form of the red tourmaline group $\left.\left[\mathrm{A}\left(\mathrm{D}_{3}\right) \mathrm{G}_{6}\left(\mathrm{~T}_{6} \mathrm{O}_{18}\right)\left(\mathrm{BO}_{3}\right)_{3} \mathrm{X}_{3} \mathrm{Z}\right)\right]$, imitating a true ruby, is for the time being, exclusively known from one spot in eastern Kazakhstan, namely the Asubulak deposit in the Kalba Mountains (Fig. 1B: 3). This gemstone is genetically associated with quartz veins inside granitic bodies. The rubellite is characterised by a reddish-brown colour and a mat lustre (Fig. 4B), in sizes of $0.5-1.5 \mathrm{~cm}$. Larger transparent, superior-quality specimens with a solid structure fit for jewellery purposes are rather exceptional.

\subsection{Spinel}

The mineral name refers to the crystal shape (Latin spinella) which resembles a small thorn of conchoidal fracture. The eastern Kazakhstan provenance bound to ultramafic rocks (e.g., Gargiulo et al., 2013). Within the study area, it is represented by a range of magnesium-aluminium $\left(\mathrm{MgAl}_{2} \mathrm{O}_{4}\right)$ mineral components. The local spinel gemstone variety ( $\mathrm{MgO} 28 \mathrm{wt}$ \% , $\mathrm{Al}_{2} \mathrm{O}_{3} 72 \mathrm{wt}$ \% $)$ is occasionally found in the polymetallic deposits of ultramafic peridotite bodies (Asubulak Formation) of the Rudno (Ore) Altay in the northern part of the territory (Fig. 1B), consisting mostly of olivine and pyroxene minerals. Although small in size (usually $0.3-0.5 \mathrm{~cm}$ ), these deep-red coloured minerals, typically of cathedral crystal form, are very decorative and of superior quality, thus predestined for jewellery.

\subsection{Turquoise}

This is one of the most beautiful, bluish and greenblue gemstones; it has been well known since Antiquity. The eastern Kazakhstan turquoises, as hydrous phosphates of copper and aluminium that produce a wide range of green-coloured variants, show an admixture of various chemical elements (CuO 10 wt.\%, $\mathrm{Al}_{2} \mathrm{O}_{3} 36$ wt.\%, $\mathrm{P}_{2} \mathrm{O}_{5} 34$ wt.\%, $\mathrm{H}_{2} \mathrm{O}$ 19 wt.\%) and variable concentrations of organic substances. The main turquoise host body, originating from percolation of acidic solutions into pre-existing minerals, is found at the Zyryanovsk mine of the Rudno Altay (Fig. 1B: 11). The present regional geographical occurrence of turquoise presupposes formation in geo-settings affected by periodic past-climate aridifications with deep bedrock weathering (Schumann, 2006), in conjunction with the regional orogenic activity. The local turquoise variant displays characteristic copper-sulphide cavity fillings in the formerly weathered and fragmented volcanic rocks (Fig. 6A). This aesthetic gemstone has traditionally been used in local jewellery manufacture and is found in prehistoric and early historical burial sites (Fig. 7B, D).

\subsection{Rhodonite}

The east Kazakh rhodonite $\left(\mathrm{Mn}^{2+} \mathrm{SiO}_{3}\right)$ is a highly decorative gemstone found in the same polymetallic deposits as crystal quartz and centred in the Rudno Altay region (Chekmar Site) (Fig. 1B: 14). Its chemical composition is relatively uniform (MnO 30-46 wt.\%, FeO 2-12 wt.\%, $\mathrm{CaO} 4-7$ wt.\%), rendering a mostly pinkish and rosy colour to it. The main orefield is structured by basalt-andesite-rhyolite (D2efD2gv) and sedimentary argillite-silt (D2ef-D3f) facies. The contact between retinues is tectonic, dipping steeply. The productive rhodonite-containing lentiform bodies are vertically oriented, 1.0-11.5 m in thickness, over a distance of 55-65 m. Regional forms are presented by tectonic breccias disintegrated by frequent cracks into which secondary minerals (iron and manganese hydroxides) percolated. The breccias include greyish-white veined aggregates 

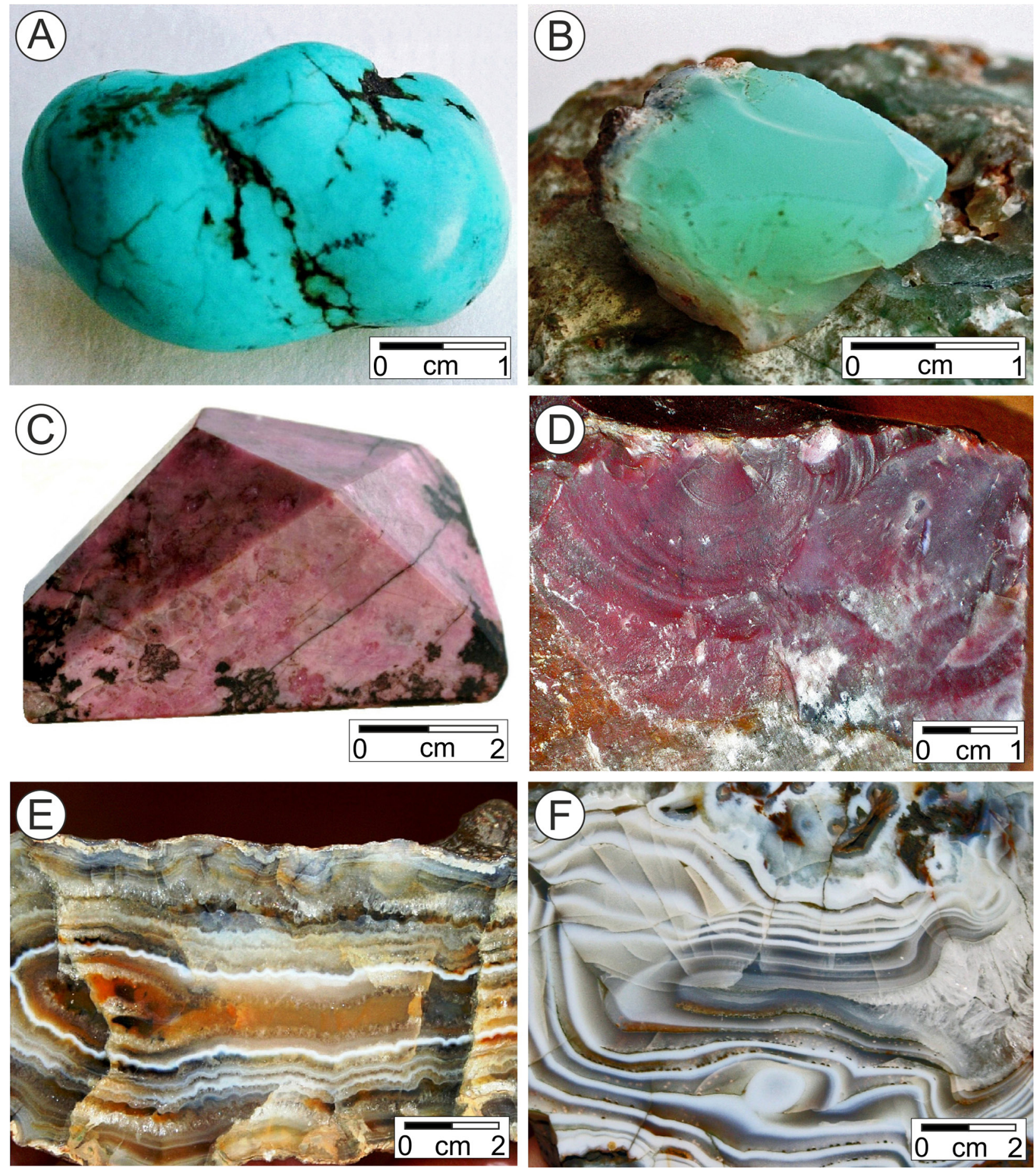

Fig. 6. Gemstones of eastern Kazakhstan

A - Turquoise (Zyrianovsk mine, Rudno Altay); B - Chrysoprase (Chernikhiv deposit, Kalba Mountains); C - Rhodonite (Chemkar deposit, Rudno Altay); D - Chalcedony (Aliyan/Del'begetey Formation, Kalba Mountains); E Agate (Aliyan deposit, Kalba Mountains); F - Agate (Maloye Karasy deposit, Kalba Mountains). Mineralogy Museum EKSTU (A-C, E-F); field sample (D)

and nests of chalcedony quartz. The bulk of the local rhodonites is represented by dense, shallow-grained and isometric cryptocrystals with weak mother-ofpearl nodules of white colour with pinkish spots of varying intensity. The present composition includes rhodonite and bustamite (30-90 vol.\%), rhodochrosite and Mn-calcite (10-30 vol.\%), quartz (0.5 vol.\%), epidote $(0.3$ vol. $\%)$ and, marginally, fuchsite. 

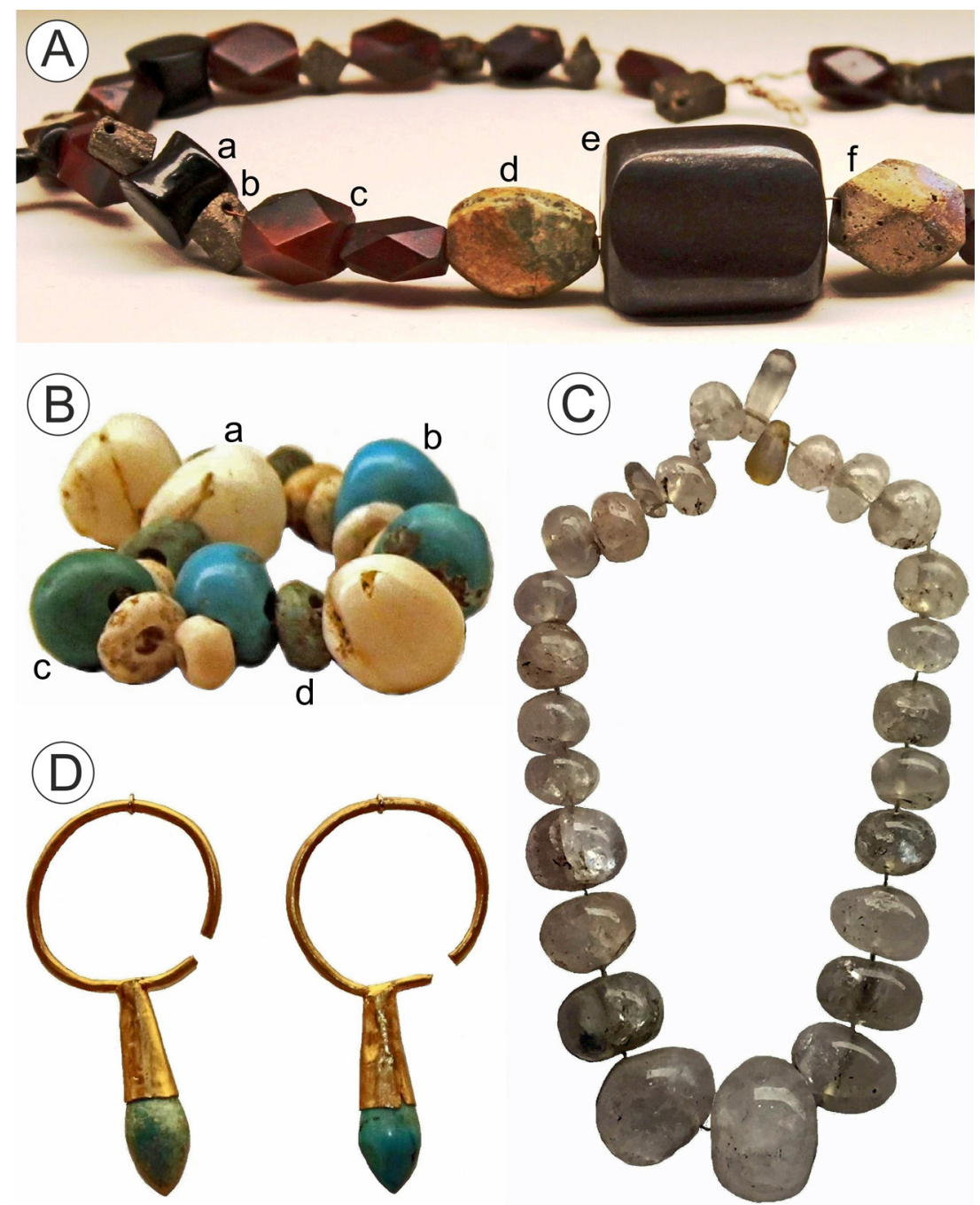

Fig. 7. Kazakh gemstones and decorative rocks in prehistoric art of the ancient Saryarka (homeland of nomadic Scythian-Saks' and Sarmatian early Iron Age tribes) and the historical Hun and Mongol ethnic groups (Saparov et al., 2018). The Scythian-Sarmat elite burial mound ornaments $\left(6^{\text {th }}-2^{\text {nd }}\right.$ century BC)

A - Pendant of facetted and polished coloured stones - ortite (allanite), porphyry, dark red garnets, marble onyx, tourmaline and zircon (a-f) (Lebedevka burial complex, western Kazakhstan); B - Bracelet of white quartz, turquoise, jade and chalcedony (a-d) (Taldy 2 burial complex, Karaganda Region, central Kazakhstan); C - Quartz (rock) crystal necklace (Lebedevka burial complex, western Kazakhstan); D - Gold earrings with cone-shaped turquoise pendants (Akbeyit burial site, eastern Kazakhstan). All stone types are present in the Altay region. National Museum of Kazakhstan, Nur-Sultan. Photographs by the author

The local rhodonite is genetically bound to an ancient volcano-sedimentary environment. The original submarine volcanic activity produced manganese oxide ores that are overlain by sedimentary carbonate formations which gradually converted into massive rhodochosite-bustamite-rhodonite silicates. The rich polymetallic and gemstone deposits at Chemkar have a major potential for future exploitation of a high-quality rhodonite. The polished stone possesses supreme decorative properties (Fig. 6C).

\subsection{Labradorite}

Labradorite, a feldspar mineral of the plagioclase series $\left[(\mathrm{Ca}, \mathrm{Na})(\mathrm{Al}, \mathrm{Si})_{408}\right]$ and among the most decorative stones in the study area, is found as discontinuous veins in mafic igneous rocks at the contact with metamorphic bedrock formations, mainly in the Rudno Altay area (Fig. 1B: 15). The local variants are characterised by distinctive blue colours and a shining lustre. Chemically, the main constituents of the Beloulbinskoe-southern Altay mineral zone are $\mathrm{SiO}_{2}\left(68\right.$ wt.\%), $\mathrm{Al}_{2} \mathrm{O}_{3}\left(19\right.$ wt.\%), $\mathrm{Na}_{2} \mathrm{O}(10 \mathrm{wt} . \%)$ and 
$\mathrm{CaO}$ (3 wt.\%). The zone consists largely of granites interspersed by metamorphic pockets containing, apart from labradorite, also highly decorative jasper variants. Prognoses for the high-quality granite host rock amount to a yield of $>100$ million $\mathrm{m}^{3}$ for industrial purposes (Chernenko, 2007).

\subsection{Chrysoprase}

This is a cryptocrystalline form of silica (chalcedony), represented by colourful, mostly light greenish varieties, reflecting percolation of mainly nickel minerals or occasionally gold, giving the characteristic yellowish colour. Occurrences of Kazakh chrysoprase are currently limited to a few, yet relatively, rich sites (e.g., Sachanbiński et al., 2001). In eastern Kazakhstan, these are mapped in the Kalba Highlands in the southeast and in the Semipalatinskoye Pri-Irtyshiye in the northeast of the territory (Fig. 1B: 12a, c); both places have quality variants. Smaller occurrences are also known from the Rudno Altay (Glubokoye District) (Fig. 1B: 12a-d). The colour of the local chrysoprase ranges from white to blue-green, depending on the admixture of $\mathrm{Ni}$ compounds in the intergrain texture. The content of nickel in the chrysoprase varies (0.3-3.3 wt.\%). Principal gemstone deposits are located near the Maloye Karasy and Belogorskiy settlements in the Kalba Range foothills; these were mapped in the early 1970s (Dyachkov et al., 1996). Here a wide chrysoprase diversity occurs within a small area (c. $10 \mathrm{~km}^{2}$ ) with a total estimated extractable volume of $c .3 \mathrm{~m}^{3}$. The local chrysoprase has a pale green to bluish-green colour with uneven spots which reduce the artistic/decorative qualities of this gemstone (Fig. 6B). Another site in eastern Kazakhstan for chrysoprase (and mercury), the Kyzylchar deposit (Fig. 1B: 12b), was found in a zone of structural orogenic cracks containing nodules and veins of chrysoprase as a result of andesite bedrock lateritisation. Several chrysoprase mineral occurrences are known from Gorno Altay (Gusev, 2007). This gem is principally destined for jewel processing.

\subsection{Agate}

Agates, filling cavities of pre-existing igneous bedrock formations (Lyutoev, 2004), are found in eastern Kazakhstan as rhythmically zoned concentric and stratified accretions of chalcedony microcrystalline variants with inclusions of carbonates, zeolites, seladonites, goethite and other minerals. Locally exposed agates are found as secondary aggregates together with chalcedony, chrysoprase and jasper in volcanic rocks, hydrothermal veins and within the upper crust of weathering of metamorphosed carbonate and carbonate-clayey rocks. Regional agate deposits are primarily associated with the trachybasalt-trachyiliolitic volcanic series of the Semeitau Type (T1) and their analogues in the Kara-Adir and Kyzyl-Adir Ranges in the western part of the Manrak Mountains. Agates also occur in formations of Hercynian-age orogeny in the andesite-basaltic (P2-T1) series in the Rudno Altay, in the Kalba Range and in the basalt-riodacite-andesite series of the Zharma-Saur Formation at the localities of Tarbagatay, Manrak, Saure and Saikan (Fig. 1B: 13a-d) (Chernenko \& Chlachula, 2017).

In the Del'begetey granite formation in the north-central part of the territory, south of the River Irtysh, there are agate layers with a mosaic of colours ranging from white, blue and yellow to intense red (Fig. 6D). These variegated siliceous solutions originated during the last stage of magmatic activity that filled micro-lithic cavities and cracks in leukogranite of apical parts of the enclosing massive granite bodies. The chalcedony specimens illustrated here originate from the key Aliyan and Maloye Karasy sites of the Kalba Formation which hosts the mineral lenses that laterally extend for about 1,150 $\mathrm{m}$ with gemstone veins of fine white or bluish agates of a scalloped and wool-striped texture (Fig. $6 \mathrm{E}, \mathrm{F})$. Specific agate variants are texturally painted by iron hydroxide in red-brown and yellow-brown colour tones. The local agates are used mainly in the decorative gemstone industry due to the aesthetic structure that allows for cutting and surface-polishing treatment of finished ornaments and goods of an appealing appearance.

Another site of provenance of agate is the Saikan site, associated with tuff-lava liparite-dacites found at the contact with diabase porphyries. Here, mineral-enriched crystalline zones are traced well by homogeneous bluish-grey chalcedony and striped agate. Mineralised veins are filled by concentric, high-quality chalcedony concentrations that are pre-conditioned by zeolithisation. Secondary alluvial and proluvial mineral deposits of agates distributed on the northwestern flanks of the Semeitau Hills formed in weathering processes that released concentrations of gemstones from the original igneous and metamorphic formations on slopes and alluvial fans, laterally extending from the foothills into adjoining river valleys. These are exposed locally in trenches and small depressions where the clayey alluvial sediments covering them eroded away. The rich mineralisation of amygdales of agate 
and chalcedony at the Aktobe locality is characterised by a broad facies variety. Among these, there is onyx, spotted mushroom-like onyx (black-white variety), dendritic white- and brown-bended chalcedony, red-coloured cornelian, cornelian onyx and sardonyx. The size of these specific mineral forms, shaped as irregular nodules, ranges from a few millimetres up to $15-30 \mathrm{~cm}$ in diameter. The east Kazakh agates are generally very strong in structure and decorative.

\subsection{Nephrite}

Nephrite, a microcrystalline silicate of calcium and magnesium of dense structure and greenish or bluish colour varieties, is known from only a few places in eastern Kazakhstan, in comparison to more extensive occurrences in Gorno Altay (Gusev, 2007). In nearby locations, the Kuray and the Terekta Range, nephrite and jade are encountered in ultramafic rocks of the southern Altay orogenic belt, and the valley of the River Argut, adjoining the study area in the north, confined to a large body of serpentinites in the eastern part of the Katun' Range. Some isolated dark-green and structurally homogeneous nephrite pebbles, $1-5 \mathrm{~cm}$ in size, were found in secondary position in alluvial gravels of the River Koksu (a left tributary of the River Argut) and the upper reaches of the River Bukhtarma within the nearest Russian-Kazakh border zone in the Plateau Ukok direction (Fig. 1B: 21a-b). The original gem-bearing formations are most likely represented by serpentine-olivine-tremolite rocks within gneissic shales. On the other (Gorno Altay) side, the Tomul-Muinokskoy ore field with variegated jade segregations of bright-green to greenish-grey colour is considered the most promising for industrial exploitation, with the mineral content in the rock not exceeding 1\% (Gusev, 2020).

\subsection{Jasper}

As an aggregate of a micro-granular spotted quartz of the chalcedony series with inclusions of other mineral phases and impurities (Kostov, 2010), jasper is one of the most widely distributed decorative stones in the wider Altay area (Fig. 8) with a long history of exploitation and artisanal use (Shvetsov, 1998; Simonov et al., 2010) (Fig. 10). Well-known local variants are represented by pied or speckled siliceous stones with a dense and well-polishable structure consisting of micro-quartz, often with an admixture of chalcedony, oxides of iron, alumini- um and fibred minerals of different colours, most frequently red, green and blue. Yellow, grey and black varieties also occur.

The major multi-coloured jaspers in eastern Kazakhstan are associated with the Palevoye and Ridderskaya breccias in the Kyzyl-Tube Mountains and the Kalba Range (Fig. 1B: 16a, b). Jasper deposits, hosting chrysoprase, are found in the Glubokoye District close to the town of Ridder (Ridder-Sokol'noye sites), and in the Glubokoye deposits. Another site is located in the Cholzun Range on the Russian-Kazakhstan border. The Rudno-Altay jasper is most famous for its wide diversity and attractive appearance with a range of colours (Fig. 8A-E). The local rock bodies have been exploited since the $18^{\text {th }}$ century and have acclaimed world fame. Several unique works of art made from Rudno Altay jasper are on display in major European museums (Fig. 10C). Field exploration works are currently projected on the southwestern flanks of the Bistrushinskaya Unit, near the Bistrushinskaya mine (Z. Chernenko, pers. communication, 2016). In addition to various jasper varieties, there are also high-quality marbles. The reserves of jasper in the nearby Russian Gorno Altay amount to about $400 \mathrm{~m}^{3}$ for 1 -m-depth of the porphyry rhyolite mineral formation (Gusev, 2007).

\subsection{Fluorite}

Among other coloured and ornamental stones (Ziskind, 1989) of aesthetic appearance, there is fluorite $\left(\mathrm{CaF}_{2}\right)$ with the best-known geological occurrence associated with the Kalba Range and the world-famous Karadzhal deposit in the northern Almaty Region (Fig. 1B: 18a, b). This mineral is characterised by a translucent sparkling bluish-violet colour with a high range of spectral variegation. In spite of its attractive appearance (Fig. 5E, F), fluorite represents a bulk raw material in the local metallurgy. More than 200 sites with fluorite occurrences have been mapped in the bordering Gorno Altay in various fluorite-enriched quartz and sulphide formations (Gusev, 2007). The transparent polychromic and structurally compact types are best fit for decorative applications.

\subsection{Decorative rocks}

Except for the coloured precious and semi-precious minerals, a variety of quality rocks that are widely distributed on the territory of eastern Kazakhstan 

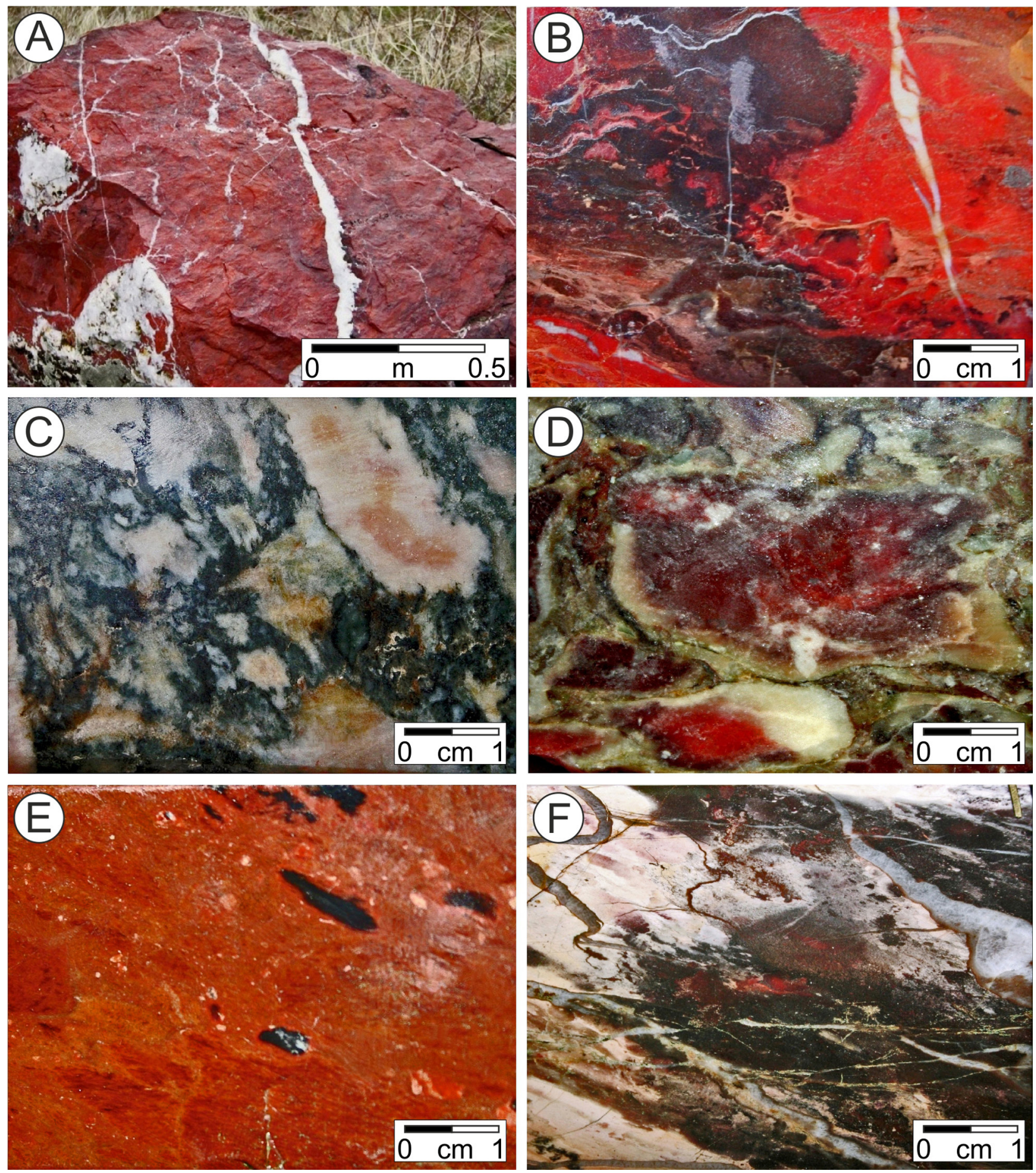

Fig. 8. Gemstones of eastern Kazakhstan. Jasper (Ridder - Sokol'noye deposit, Rudno Altay). Mineralogy Museum EKSTU (B-E); field samples (A, F)

have major potential for large-scale exploitation and utilisation. Among the most aesthetic ones, available in large quantities, are fine-grained granites and metamorphic granitoid schists, porphyry, tuffs, tuff sandstones, serpentinites, limestones and marbles (Fig. 9C-F). Prognoses for regional supply for the last-named are c. 30 million $\mathrm{m}^{3}$, with principal sites at Bukon' (Ulan District), occupying a total area of about $3 \mathrm{~km}^{2}$, Baybura in the western Kalba area and Troyskoye in the Semipalatinsk region (Charskiy District) with estimated resources of $>500,000 \mathrm{~m}^{3}$ (Chernenko, 2015). All these rocks are industrially exploited for construction work (exterior and interior decorations). 

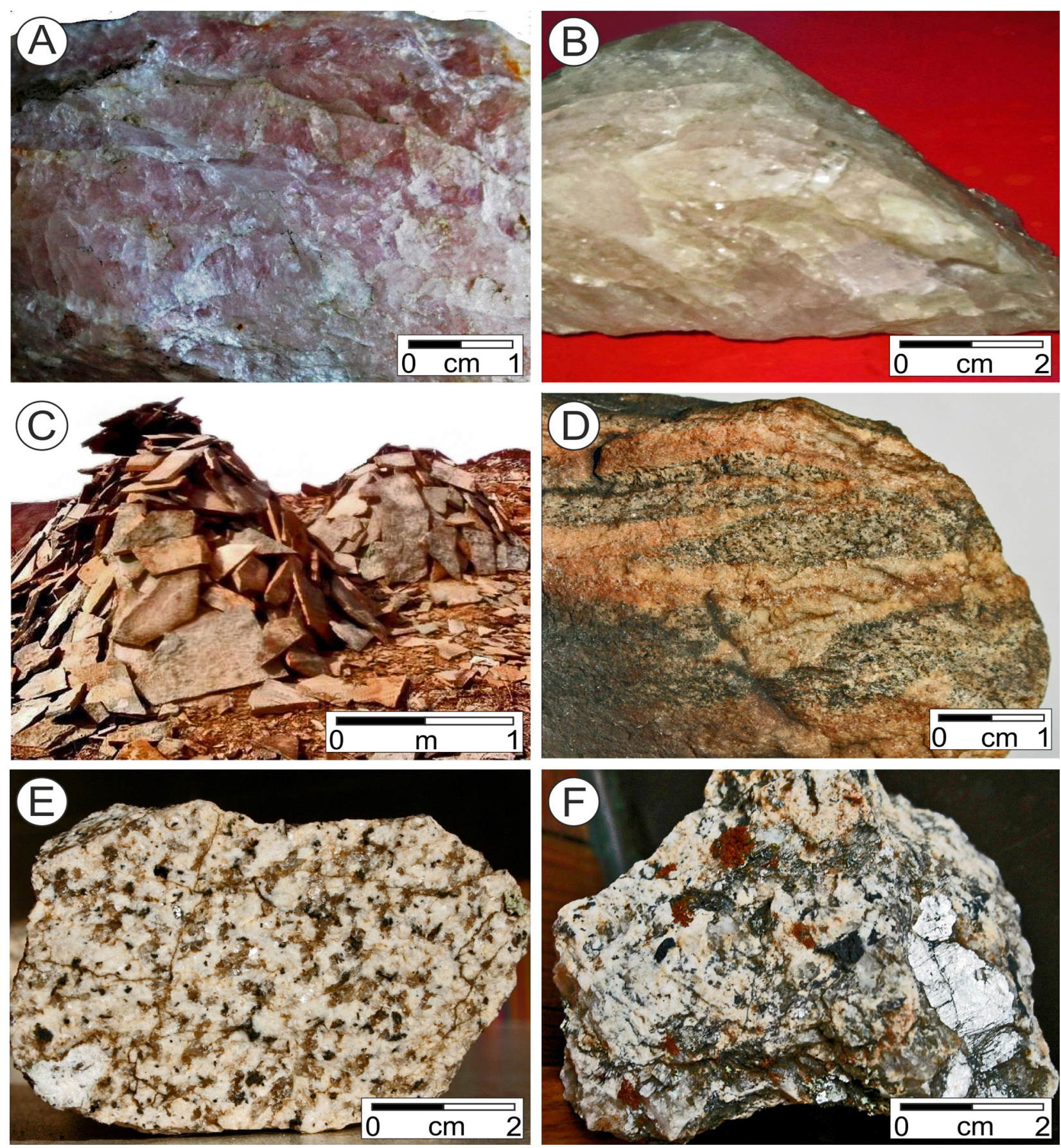

Fig. 9. Gemstone minerals and decorative rocks of eastern Kazakhstan. Mineralogy Museum EKSTU (A, B); field sample (C); author's collection (D-F)

A - Quartz (Karaozek deposit, Kalba Formation); B - Microline quartz (Targin deposit, Rudno Altay); C - Marble (Novo-Taubinskoye deposit, Ulansk District, Kalba Formation); D - Gneiss (Rudno Altay); E - Granite (Kalba Formation); F - Granite (southern Altay)

\section{Utilisation and applications of the eastern Kazakhstan gemstones}

As presented above, the territory of eastern Kazakhstan with its complex structural formations, hosts a diversity of gemstones suitable for both jewel and artwork processing. Utilisation of local gemstones reflects their appropriate physical characteristics and corresponding mineralogical qualities (Balakirev et al., 1979). Their prospective profitability for the industry depends on the value of 

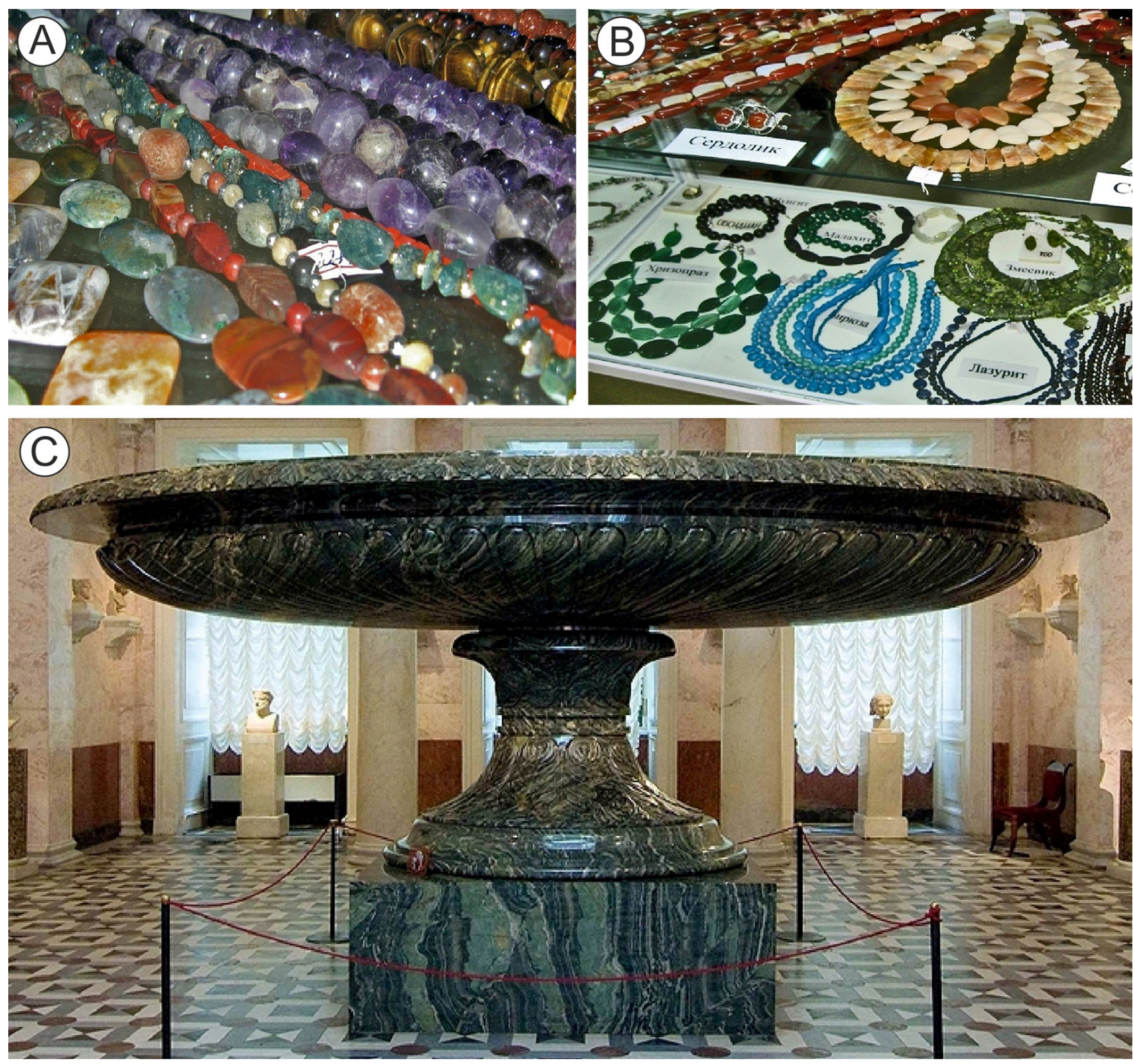

Fig. 10. Kazakh coloured stones in historical and contemporary artwork

A-B - Cut and polished decorative stones from eastern Kazakhstan - jasper, amethyst, chalcedony, agate, serdolik (carnelian agate) and some others, at a jewellery shop in Ust'-Kamenogorsk; C - The Grand Kolyvan Vase ("Tsar Vase") - the largest decorative piece of art made from Rudno Altay jasper at the famous Kolvvan factory between 1828-1843, as ordered by Tsar Alexander I. The piece is made from an original stone monolith that was 8 metres in size; the diameter of the ellipsoid vase is $5 \mathrm{~m}$, its height $3.22 \mathrm{~m}$ and weight $19 \mathrm{t}$. After being transported across southwestern Siberia by sledges drawn by 154-180 horses, and crossing the Urals on river boats via Kama-VolgaNeva to St Petersburg, the vase was installed in the Hermitage in 1849 (Mavrodina, 2017). Photograph courtesy of the Hermitage, St Petersburg

raw materials and the current market price of jewellery products (Smith, 1980; Rid, 1986; Kornilov \& Solodova, 1986). Coloured stones from central Asia have long been preferred for their appealing appearance (e.g., Goodwin, 1996; Pugachenkova, 1996; Domínguez-Bella, 2018). The most expensive jewellery decorations and luxury goods have been made from rare, mainly transparent, gemstones. Local quality and quantity of diamonds do not allow for their use in the jewel trade. For this purpose, particularly bright and more widely distributed, high-quality minerals such as coloured tourmalines and rock crystals are employed. An even higher potential for Kazakhstan, as well as the Russian Gorno Altay gemstone industry, can be ascribed to decorative and easy-to-work semi-precious stones with rich regional resources, such as jasper, agate and chalcedony (Fig. 10A, B). 
Of certain importance are deposits of decorative rocks used for building constructions and home interior industry purposes, such as coloured granites, gneiss or marbles (Fig. 9C-F), the resources of which are fairly opulent in the country (Beldeeva \& Somin, 2014).

The most valuable precious stones of Kazakhstan (sapphire, ruby, topaz, chrysoprase and turquoise) are often combined with precious metals (gold, platinum and silver). The final price of the finished products reflects, except for the raw gemstone value, the direct costs of geological exploration and exploitation and of industrial processing/ treatment of those materials. Among the semi-precious stones, the bulk-carved minerals such as jasper or fine-grained coloured quartz are mainly used for artwork and souvenirs. The widely distributed hard rocks with suitable mechanical qualities, such granites or marbles, are used as decorative materials.

Application of gemstones has changed significantly during the last decades in connection with the development of exact instruments in high-tech industrial and laboratory employments (O'Donoghue, 1988). The Kazakh transparent quartz and tourmalines are applied in the optical industry; agate/chalcedony are used in high-precision devices for measuring. Jewellery use of natural stones has sharply decreased, following global trends, with increased production of synthetic minerals and cheap gemstone imitations (Nassau \& Nassau, 1980; Kane, 2009; Nassau, 2009), but also because of a drop in demand on the national market.

\section{Discussion: perspectives for the gemstone industry in Kazakhstan}

In view of the growing interest in natural gemstones on the global (mainly eastern) markets, the principal problem of the Kazakh gemstone industry lies in activation of exploration and development of mineral mining based on modern resource extraction and processing. These enable exploitation of new non-metallic mineral sites, but also an effective reuse of formerly mined gemstone-bearing deposits. Applications of scientific research linked to these economic activities in terms of preparatory geological mapping, mineral treatment, fieldwork management as well as environmental impact assessment at particular mining sites have become a priority. These activities contribute to a better knowledge abroad of the variety and beauty of local gemstones.
Despite the fact that there are major non-metallic mineral resources, reflecting the structure of igneous and metamorphic bedrocks, there has been only minor activity in gemstone exploitation and industry in the Republic of Kazakhstan since the 1990s. In the region of eastern Kazakhstan, from where most of the coloured stones originate, just a few private enterprises have been involved in gemstone prospection, exploitation and processing during the last decades. This is because of limited terrain reconnaissance and mapping of suitable geological formations and/or technically inaccessible precious-mineral host rocks whose occurrences are known (e.g., Sapargaliev \& Kravchenko, 1999). Another aspect is the dramatic reduction of present field activities in comparison to systematic exploration during Soviet Union times in this geologically strategic area. Most of the currently known sites of gemstone provenance were a byproduct of prospection activities by the state. At the present time, there are more than 120 mapped places of gemstone distribution on the territory of eastern Kazakhstan, of which about 20 per cent (24 locations) are economically and geologically suitable for industrial mining (Chernenko \& Chlachula, 2017). Currently, there are more than 45 bedrock deposits and sedimentary placer occurrences of supreme-quality decorative stones, apart from other non-metallic mineral placements and unofficial mineral reserves (Scherba et al., 2000; Chernenko et al., 2014). Only a few, such as the Del'gebeteyore mining by the company Emerald Ltd., is operative. The mineral exploitation must comply with the Environmental Protection Law no. 521 (2007) „On approval of the list of environmental protection objects of special ecological, scientific and cultural significance."

The extraction of the traditionally most precious gemstones found in low concentrations and/or jeweller quality, such as emeralds (green beryl) or diamonds, is not commercially viable. The revival in mining of mainly more widely distributed and varied semi-precious stones is predetermined by implementation of innovative scientific approaches based on analytical assessment of localised ore-concentrations in the non-metallic formation zones and elaboration of modern techniques used in the detection of precious mineral-bearing deposits. Genetic rock-formation models of particular gemstone-bearing deposits may project a closer spatial prediction of occurrences of precious stones (e.g., Garnie et al., 2008). This concerns primarily the main gemstone distribution areas of the Rudno Altay and the Kalba and Zharma-Saur Mountain areas. The new gemstone locations will increase the region's mineral potential and attract investments, 
currently limited to gemstone mining sites such as Yubileynoe (coloured tourmaline), Gromovskoye (topaz) and Izumrudnoye (emerald) (Fig. 1).

Introduction of modern analytical techniques aimed at quantitative and qualitative assessment of industrially significant gemstone resources equally help to reduce expenses in field mapping. More effective exploration approaches based on regionally diagnostic geochemical characteristics of the most valuable crystalline mineral-hosting formations and gemstone-bearing intra-structural geological sites may add to their economic profitability. The same holds true with respect to extraction of profitable mineral deposits and artisanal elaboration in ornamental and precious stone processing. Advanced natural gemstone spectroscopy identification methods, together with other formerly elaborated analytical procedures (Ponahlo, 2000; Jenkins \& Larsen, 2004), provide the basis for fiscal assessment of the profitability of prospective metallogenic resource field operations in eastern Kazakhstan (e.g., Kievlenko, 1989; Chernenko et al., 2012). Recipients are the prospecting geological survey and mining companies, industrial natural resource exploitation enterprises active in eastern Kazakhstan, as well as local government institutions with integrated environmental and regional development organisations. Results of experimental laboratory work can be used by geological organisations and companies that are active in gemstone processing, in decorative industrial and artisanal use as well as jewel production. Finally, the diversity of gemstone occurrences in the wider Altay region has potential where the development of gemmo-tourism is concerned (Gusev, 2007, 2020).

\section{Conclusions}

Historically, eastern Kazakhstan has been a key area of origin of coloured stones. It is also one of the most promising regions of central Asia for gemstone exploration and their industrial/jewellery use, next to world famous places such as Tajikistan or Afghanistan (Smith, 1998; Bowersox et al., 2000; Natkaniec-Nowak, 2010; Sorokina et al., 2015). The local stones, intrinsically valued for over thousands of years, represent major, only partially exploited riches of the country. Except for traditional decorative stones, such as the variegated high-quality jasper and rhodonite from Rudno Altay, as well as major deposits of local decorative rocks, the prospection and exploitation of the rarer, albeit more highly valued precious stones including topaz, ruby and coloured tourmaline, has a market-significant po- tential. In spite of the immense mineral resources, the Kazakh gemstones industry is largely limited to small-scale, and almost exclusively local, mining activities. The major precious non-metallic mineral bodies justify prospection for new gemstone-hosting deposits that could usher in a revival of the once flourishing decorative stone industry and trade. Notwithstanding the production of synthetic stones, genuine precious stones will remain the irreplaceable raw material for fine art and jewellery. The political stability of the Republic of Kazakhstan and present legal system are additional positive aspects for development of a gemstone industry.

\section{Acknowledgements}

The study of eastern Kazakh gemstones was facilitated by the Mineralogy Museum and Laboratory of the EKSTU, Ust'-Kamenogorsk, following personal fieldwork that was supported by the IRBIS ngo and the Ministry of Environment of the Czech Republic (Project RP-6-2005). I thank in particular Dr Zynaida Chernenko (Department of Ore Geology and Mineralogy, EKSTU Ust'-Kamenogorsk) for valuable technical mineral information and supplementary illustrations concerning gemstone occurrences in eastern Kazakhstan; Professor Anatoly I. Gusev (Department of Geology, Byisk State University, Russian Federation) and Professor Mikhail T. Krupenin (Institute of Geology and Geochemistry, Urals Branch, Russian Academy of Sciences, Ekaterinburg) for assistance in identification of some mineralogical samples on gemstone-hosting regional geology. Professor Lucyna Natkaniec-Nowak (Faculty of Geology, Geophysics and Environmental Protection, AGH University of Science and Technology, Kraków, Poland), Dr Edward Little (Geological Survey of Canada, Calgary) and Dr Stanislaw Koszela (Institute of Geology, Adam Mickiewicz University, Poznań, Poland), as well as three anonymous reviewers, provided valuable comments, corrections and suggestions contributing to the final version of this paper.

\section{References}

Akishev, K.A., 1978. The Issyk Barrow. The Art of Saks of Kazakhstan. Art, Moskva, 142 pp. [in Russian].

Balakirev, V.G., Kievlenko, Ye.A. \& Nikolskaya, L.V., 1979. Mineralogy and Crystal Physics of Earth Silicon Jewellery Variety. Nauka, Moscow, 150 pp. [in Russian].

Barfield, T., 1989. The Perilous Frontier: Nomadic Empires and China. Cambridge, Mass., Blackwell Press, 303 pp. 
Baumer, C., 2016a. The History of Central Asia. Vol. 1: The Age of the Steppe Warriors. I.B. Tauris Press, 372 pp.

Baumer, C., 2016b. The History of Central Asia. Vol. 2: The Age of the Silk Roads. I.B. Tauris Press, 288 pp.

Baumer, C., 2016c. The History of Central Asia. Vol.3: The Age of Islam and the Mongols. I.B. Tauris Press, 408 pp.

Beldeeva, E. \& Somin, V., 2014. Green economy principles in Altai Krai. Himalayan and Central Asian Studies, 18, 232-249.

Bowersox, G.W., Foord, E.E., Laurs, B.M., Shigley, J.E. \& Smith, C.P., 2000. Ruby and Sapphire from Jegdalek, Afghanistan. Gems and Gemology 36, 110-126.

Bukanov, V.V., 2011. Russian Gemstones encyclopedia. Granit, Praha, 472 pp.

Chernenko, Z.I., 2007 Industrial Types of Deposits of Minerals of Precious Stones. EKSTU, Ust-Kamenogorsk, 92 pp. [in Russian].

Chernenko, Z.I., 2011. Crystallography and Mineralogy. EKSTU Press, Ust-Kamenogorsk, 45 pp. [in Russian].

Chernenko, Z.I., 2015. Analysis of the perspective marble and marmorized limestone deposits as facing and ornamental stones in East Kazakhstan, Vestnik of the EKSTU (Earth Sciences) 3, 15-17 [in Russian].

Chernenko, Z.I. \& Chlachula, J., 2017. Precious and decorative non-metallic minerals from East Kazakhstan: geological deposits and present utilisation. Proceedings $17^{\text {th }}$ International Multidisciplinary Scientific Geoconference SGEM, Sofia-Albena 17, Science and Technologies in Geology Exploration and Mining, STEF92 Technology Press, Sofia, pp. 447-454.

Chernenko, Z.I., Bocharova, A.E. \& Alexandrova, M.A., 2012. Mineralogy and Conditions for Formation of Ornamental and Precious Stones of East Kazakhstan and Perspectives of Their Use. Ust-Kamenogorsk. Serikbaev ESKTU Press, Ust-Kamenogorsk, 10 pp. [in Russian].

Chernenko, Z.I., Goryainova, A.A., Kaloshin, K.A. \& Zorkina, A.G., 2014. Stereoscopic placement of deposits and occurrence of precious and ornamental stones of East Kazakhstan. [In:] „Creativity and Innovative Development of Kazakhstan", Ust-Kamenogorsk, [in Russian].

Chlachula, J., 2010. Pleistocene climate change, natural environments and Palaeolithic peopling of East Kazakhstan. In Eurasian Perspectives of Environmental Archaeology. Quaternary International 220, 64-87.

Chlachula, J. \& Seljanina, E., 2007. Quaternary investigations of southern Altai, East Kazakhstan. [In:] Modern Approaches to Biodiversity Protection in the Context of Steady Development Achievement of the Republic of Kazakhstan, Ust-Kamenogorsk, pp. 18-21.

Christian, D., 2018. A History of Russia, Central Asia and Mongolia. Vol. II: Inner Eurasia from the Mongol Empire to Today 1260-2000. Willey Blackwell, Chichester, 619 pp.

Chugunov, K., Parzinger, H. \& Nagler, A., 2003. Der skythische Fürstengrabhügel von Arzhan in Tuva. Vorbericht der russisch-deutschen Ausgrabungen 20002002. Eurasia Antiqua 9, 113-162.

Chupakhin,V., 1968. Physical Geography of Kazakhstan. Alma-Ata. „Mektep“ Press, 260 pp. [in Russian].
CIBJO, 2012. The Gemstone Book. CIBJO Coloured Stone Commission. The World Jewellery Confederation, 63 pp.

O'Donoghue, M., 1988. Gemstones. Chapman \& Hall, London, $372 \mathrm{pp}$

Domínguez-Bella, S., 2018. The Encyclopaedia of Archaeological Science. Willey on-line Library. https://doi. org/10.1002/9781119188230.saseas0251

Dyachkov, B.A., Chernenko, Z.I. \& Hohlov, P.I., 1996. Decorative and Ornamental stones of East Kazakhstan. East Kazakhstan CSRI Press, Ust-Kamenogorsk, vol. 7, pp. 1-6 [in Russian].

Dyachkov, B.A., Mayorova, N.P. \& Gavrilenko, O.D., 1998. About microlithic bunches in granite of the Delbegeteysky complex. [In:] Geology of Kazakhstan, vol. 3. pp. 59-70, KAS Press, Almaty [in Russian].

Dyachkov, B.A., Mayorova, N.P. \& Chernenko, Z.I., 2014a. History of East Kazakhstan geological structures development in the Hercynian, Cimmerian and Alpine cycles of tectonic genesis, part II. Proceedings of the Ust-Kamenogorsk Kazakh Geographical Society, UstKamenogorsk, pp. 42-48 [in Russian].

Dyachkov, B.A., Mayorova, N.P., Chernenko, Z.I. \& Teut Ye, V., 2014b. About metallogenic specialization of Kalba granitoids (East Kazakhstan). [In:] Materials, Kiev, pp. 59-61 [in Russian].

Erofeev, V.S., 1969. Geological History of the Southern Peripheries of the Altai in Paleogene and Neogene. Academy of Science of the Kazakh SSR, Alma-Ata, 166 pp. [in Russian].

Fersman, A.E., 1920. The Precious and Coloured Stones of Russia. The $4^{\text {th }}$ State Typography, Petrograd, vol. 1, 420 pp.; vol. 2, 386 pp. [in Russian].

Gargiulo, M.F., Bjerd, E.A. \& Mogessie, A., 2013. Spinel group minerals in metamorphosed ultramafic rocks from Río de Las Tunas belt, Central Andes, Argentina. Geologova Acta 11, 133-148.

Garnie, V., Guiliani, G., Ohnenstetter, D., Fallick, A.E., Dubessy, J., Banks, D., Vinh, H.Q., Lhomme, T., Maluski, H., Pécher, A., Bakhsh, K.A., van Long, P., Trinh, P.T. \& Schwarz, D., 2008. Marble-hosted ruby deposits from Central and Southeast Asia: Towards a new genetic model. Ore Geology Reviews 34, 169-191.

Gavrilenko, E.V., Calvo Pérez, B., Castroviecho Bolivar, R. \& Garcia del Amo, D., 2006. Emeralds from the Delbegetey deposit (Kazakhstan): mineralogical characteristics and fluid-inclusion study. Mineralogical Magazine 70, 159-173.

Goodwin, G., 1996. The art and architecture of Islam 1250-1800. Asian Affairs 27, 177-256.

Grigoriev, V.V. (Ed.), 1950. Kazakhstan, General Physiogeographic Characteristics. Nauka, Leningrad ,492 pp. [in Russian].

Grigorovich, M.B., Petrov, S.B., Agocaryan, Z.A., Kuchinskaya, E.F. \& Popugayeva, L.A., 1990. Minerals of Kazakhstan. IGS AS Kaz. USR, 196 pp. [in Russian].

Gryaznov, M.P. 1980. Arzhan - a Royal Kurgan of the Early Scythian Period. Nauka, Leningrad, 61 pp. [in Russian].

Gusev, A.I., 2007. The Altai Gemology with the Basis of Gemmo-Tourism. Biysk State University Press, 187 pp. [in Russian]. 
Gusev, A.I., 2010. Classification of granitoids on the foundation of composition of biotites. Successes of Modern Science 4, 57-59 [in Russian].

Gusev, A.I., 2020. Gemology of Altai and Salair. Pedagogical State University of Biysk, 320 pp. [in Russian].

Gutsalov, S.Y., 2007. Burials of the nomadic elite in the South Ural region (mid-1st Millennium BC). Archaeology, Ethnology and Anthropology of Eurasia 30, 75-92.

Heflik, W. \& Natkaniec-Nowak, L., 2011. Gemmologia. Antykwa, ed. II, 352 pp. [in Polish].

Jenkins, A.L. \& Larsen, R.A., 2004. Gemstone Identification Using Raman Spectroscopy. Spectroscopy 19, 20-25.

Kane, R.E., 2009. Seeking low-cost perfection: Synthetic gems. Elements 5, 169-174.

Keller, P.C. \& Fuquan, W., 1986. A survey of gemstone resources of China. Gems and Gemology, Springer, 3-13.

Khazanov, A.M., 1984. Nomads and the Outside World. Univ. of Wisconsin Press, 256 pp.

Kievlenko, E., 1980. Prospecting and Evaluation of Deposits of Gem and Decorative Stones. Nedra, Moscow, 263 pp. [in Russian].

Kievlenko, E, E., 1989. Decorative Variety of Coloured Rocks of the USSR: Reference Book. Nauka, Moscow, 272 pp. [in Russian].

Kim, M.J., 2002. A Study on the Scythian gold plaques. Journal of Fashion Business 6, 1-14.

Klein, C. \& Dutrow, B., 2007. Manual of Mineral Science. $23^{\text {rd }}$ ed., New York, John Wiley, 716 pp.

Kornilov, N.I \& Solodova, U.P., 1986. Jeweller Stones. Nedra Press, Moscow, 280 pp. [in Russian].

Kostov, R.I., 2010. Review on the mineralogical systematics of jasper and related rocks. Proceedings, Archaeometry Workshop, pp. 209-213.

Kravchenko, M.M, Kaypov, A.K. \& Sidorenko, A.K., 1974. Geology of the USSR. vol. 16. East Kazakhstan. Nedra, Moscow, pp. 330-351 [in Russian].

Kuzmina, E.E., 2007. The Origin of the Indo-Iranians. Leiden \& Boston, Brill Academic Publisher, 766 pp.

Kuzmina, E.E., 2008. The Prehistory of the Silk Road. University of Pennsylvania Press, 264 pp.

Lobanov, K. V. \& Gaskov, I.V., 2012. The Karchiga copper massive sulphide deposit in the high-grade metamorphosed rocks of the Kurchum block: geologic structure, formation, and metamorphism (Rudny Altai). Russian Geology and Geophysics 53, 77-91.

Lyutoev, V.P., 2004. Structure and Spectroscopy of Chalcedony. Ural Branch RAS, Ekaterinburg, 116 pp.

Manutchehr-Danai, M., 2010. Dictionary of Gems and Gemology. Springer, Berlin -Heidelberg, 565 pp.

Martinovskiy, G.I., 2003. The Great Altay: Geology and Metallogeny. GIZ, Almaty, 145 pp. [in Russian].

Mavrodina, N.M., 2017. The Kolyvan Vase. State Hermitage Press, Sankt Petersburg, 28 pp. [in Russian].

Mitrayeva, N.M., 1990. Minerals of Kazakhstan. Gylym Press, Alma-Ata, 221 pp. [in Russian].

Mukaeva, L.N., 2008. Mineral Prospection in the Altai in the Pre-Soviet Time. Gorno Altai University (GAGU) Press, Gorno Altaisk, 344 pp. [in Russian].
Mukaeva, L.N., 2011. Search for colored stones in the Altay in the XVIII ${ }^{\text {th }}$ Century. Vestnik of the Tomsk State University (History) 344, 77-83 [in Russian].

Muratov, M.V. \& Slavin, V.I., 1953. Short Geological Characteristics of the Kalba. Academy of Science USSR, Moskva-Leningrad, 84 pp. [in Russian].

Natkaniec-Nowak, L., 2010. Mineralogy of Selected Precious and Decorative Stones of Afghanistan. AGH Press, Rozprawy i monografie, 206 pp. [in Polish].

Nassau, K., 2009. Gemstone Materials. Willey on-line Library. DOI: 10.1002/0471238961.0705131914011919. a01.pub2

Nassau, K. \& Nassau, J., 1980. The Growth of Synthetic and Imitation Gems. [In:] Freyhardt, H.C. (Ed.): Growth and Properties. Crystals (Growth, Properties, and Applications), vol 2. Springer, Berlin, pp. 1-50.

Nekhoroshev, V.P., 1967. Eastern Kazakhstan. Geological Structure. [In:] Sidorenko, A.V. \& Nedra, M. (Eds): Geology of the USSR, vol. 41, Nauka, Moskva-Leningrad, 467 pp. [in Russian].

Obruchev, V.A., 1951. Selected Works on Geography of Asia. vol. 2, Geografizdat, Moskva, 400 pp. [in Russian].

Pacekov, U.M., Jukova, A.A., Alekseyev, A.G. \& Artemeva, E.L., 1990. Minerals of Kazakhstan. IGS AS Kaz USR, Alma Ata, 196 pp. [in Russian].

Parzinger, H., 2017. Burial mounds of Scythian elites in the Eurasian steppe: New discoveries. Journal of the British Academy 5, 331-355.

Polk, P., 2012 Collecting Rocks, Gems and Minerals: Identification, Values and Lapidary Uses. Krause Publications, Iola, 304 pp.

Polosmak, N.V., 2001. Inhabitants of Ukok. Infolio, Novosibirsk, 334 pp. (in Russian).

Ponahlo, J., 2000. Cathodoluminescence as a Tool in Gemstone Identification. [In:] Pagel, M., Barbin, V., Blanc, P. \& Ohnenstetter, D. (Eds): Cathodoluminescence in Geosciences. Springer, Berlin, pp. 479-500.

Pugachenkova, G.A., 1996. The Antiquities of Transoxiana in the Light of Investigations in Uzbekistan (1985-1990). Ancient Civilizations from Scythia to Siberia 2, 1-38.

Ren, J., 2013. International Geological Map of Asia 1: 5000 000. Geological Publishing House.

Rid, P.J., 1986. Gemological Dictionary. Nedra Press, Moscow, 287 pp. [in Russian].

Sachanbiński, M., Janeczek, J., Platonov, A. \& Rietmeijer, F., 2001. The origin of colour of chrysoprase from Szklary (Poland) and Sarykul Boldy (Kazakhstan). Neues Jahrbuch fuer Mineralogie 177, 61-76.

Samashev, Z., 2011. Berel. Archaeological Institute, Taimas Press, Astana, 236 pp. [in Russian].

Samashev, Z., 2014. Tsar Valley. Archaeological Institute, Astana, 236 pp. [in Kazakh].

Sapargaliev, Ye.M. \& Kravchenko, M.M., 1999. Non-metallic mineral resources in the development of East Kazakhstan. [In:] Mineral resources of East Kazakhstan and their multipurpose use. ESTUPress, Ust-Kamenogorsk, pp. 48-54 [in Russian].

Saparov, K., Chlachula, J. \& Yeginbayeva, A., 2018. Toponymy of the Ancient Sary-Arka (North-Eastern Kazakhstan). Quaestiones Geographicae 37, 37-54. 
Sementsov, V.T., 2004. Some properties of the jewellery cordilerites of the Lyubushkinskoye deposit in Gorno Altai. Bulletin of Natural Resources of Gorno Altay (Geology, Geophysics, Hydrogeology, Geoecology, Mineral and Water Resources) 2, 57-58 [in Russian].

Scherba, G.N., Bespayev, X.A. \& Dyachkov, B.A., 2000. Large Altay (Geology and Metallogeny). RIO VAC RK, Almaty, 400 pp. [in Russian].

Schulz, S.S., 1948. Analysis of Neotectonics and Relief of the Tian-Shan. Proceedings of the Soviet Geographical Society, vol.1, Nauka, Moskva-Leningrad, 201 pp. [in Russian].

Schumann, W., 2006. Gemstones of the World. $3^{\text {rd }}$ ed., Sterling Press, New York, 272 pp.

Shvetsov A.Y., 1998. The history of the discovery and study of deposits of ornamental stones in the Altay. [In:] The Kolyvan: History, History and Art. Siberian Provinces, 1728-1998. ASU Press, Barnaul, pp. 127-140 [in Russian].

Simcikova, M., 2007. Petrological Context of Biodiversity Studies (Katon-Karagay National Park). [In:] Chlachula J. (Ed.): Biodiversity Protection of the Southern Altai in the Context of Contemporary Environmental Transformations and Socio-Economic Development, Irbis, Stare Mesto, pp. 27-35.

Simonov, V.A., Paskov, I.V. \& Kovyazin, S.V., 2010. Physico-chemical parameters from melt inclusions for the formation of the massive sulphide deposits in the Altai-Sayan Region, Central Asia. Australian Journal of Earth Sciences 57,737-754.

Smith, C.P., 1998. Rubies and pink sapphires from the Pamir Mountain Range, Tajikistan (former USSR). Journal of Gemmology 26, 103-109.

Smith, G., 1980. Jewells. Mir Publishing, Moscow, 586 pp. [in Russian].

Sokolev, S.V. \& Bulgak, L.V., 1981. Some gems from the collection of the Fersman Mineralogical Museum. Journal of the Gemmological Society of Japan 8, 99-102.

Sokolova, E.N., Smirnov, S.Z., Astrelina, I.E., Annikova, I.Yu., Vladimirov, A.G. \& Kotler, P.D., 2011. On- gonite-elvan magmas of the Kalguty ore-magmatic system (Gorny Altai): composition, fluid regime, and genesis. Russian Geology and Geophysics 51, 1378-1400. Sorokina, E.S., Litvinenko, A.K., Hofmeister, W., Haeger, T., Jacob, E.D. \& Nasridinov, Z.Z., 2015. Rubies and sapphires from Snezhnoe, Tajikistan. Gems and Gemology 15, 160-175.

Stone, D., 2004. Jewels. ONYX Press, Saint Petersburg Moscow, 94 pp. [in Russian].

Vdovina, T.A, 2001. Decorations from precious stones of the Scythian and Hun-Sarmatian periods of Gorno Altay. [In:] Cultural Heritage of North Asia, Barnaul, pp. 324-326 [in Russian].

Velikovskaya, E.M., 1946. Relief Development of the Southern Altay and Kalba and Deep Gold Placers. Bulletin of the Moscow Institute of Petrology, Geology Section 21, 57-77 [in Russian].

Velikovskaya, E.M., 1947. Pliocene and Quaternary deposits and relief evolution of Kalba. Moscow State University Press, Geology 124, 59-63 [in Russian].

Veselova, L.K., 1970. Morphostructure of the South-Eastern Kazakhstan Mountains. [In:] Geography of Desertic and Mountain Region of Kazakhstan.Nauka, Moskva-Leningrad, pp. 38-48 [in Russian].

Wang, S., Wang, Y., Liao, Y., Kang, X. \& Chen, J., 1994. Chrysoberyl in a granitic pegmatite in the Altai area, Xinjiang. Journal of the Xinjiang Institute of Technology 15, 142-149.

Weinstein, M., 2013. Precious and Semi-Precious Stones. John Wiley \& Sons, London, 191 pp.

Ziskind, M.S., 1989. Ornamental Stones. Nauka, Leningrad, 256 pp. [in Russian].

Żaba, J., 2010. The Illustrated Encyclopaedia of Minerals and Rocks. Videograf II, Chorzów, 503 pp. [in Polish].

Manuscript received: 18 November 2019 Revision accepted: 20 April 2020 